\title{
Support surfaces for pressure ulcer prevention (Review)
}

\author{
Cullum NA, McInnes E, Bell-Syer SEM, Legood R
}

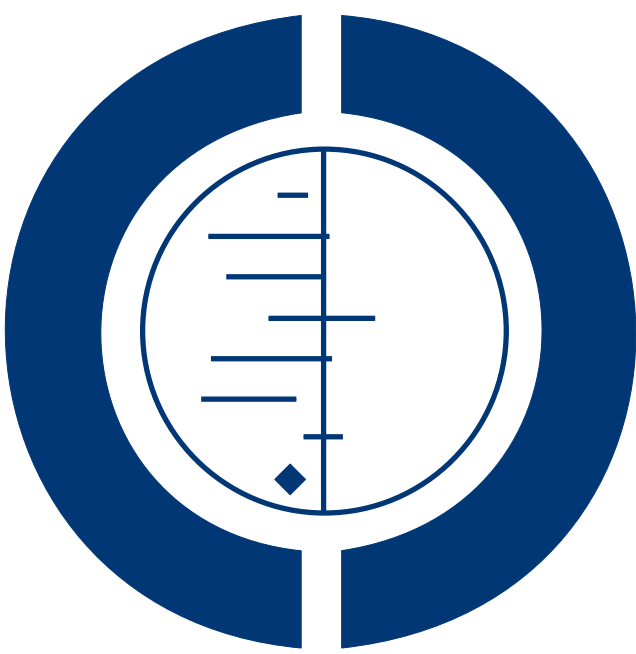

THE COCHRANE COLLABORATION $^{\circledR}$

This is a reprint of a Cochrane review, prepared and maintained by The Cochrane Collaboration and published in The Cochrane Library 2004, Issue 3

http://www.thecochranelibrary.com

\section{WILEY}


TABLE OF CONTENTS

HEADER . . . . . . . . . . . . . . . . . . . . . . . . . . . . . . . . . . . . . . . . 1

ABSTRACT . . . . . . . . . . . . . . . . . . . . . . . . . . . . . . . . . . . . . . . . . . . . . . .

PLAIN LANGUAGE SUMMARY . . . . . . . . . . . . . . . . . . . . . . . . . . . . . . . . . . . 2

BACKGROUND . . . . . . . . . . . . . . . . . . . . . . . . . . . . . . . . . . . . . . . . .

OBJECTIVES . . . . . . . . . . . . . . . . . . . . . . . . . . . . . . . . . . . . . .

METHODS . . . . . . . . . . . . . . . . . . . . . . . . . . . . . . . . . . . . . . .

RESULTS . . . . . . . . . . . . . . . . . . . . . . . . . . . . . . . . . . . . . . .

DISCUSSION . . . . . . . . . . . . . . . . . . . . . . . . . . . . . . . . . . . . . 10

AUTHORS' CONCLUSIONS . . . . . . . . . . . . . . . . . . . . . . . . . . . . . . . . . . . . . . 11

ACKNOWLEDGEMENTS . . . . . . . . . . . . . . . . . . . . . . . . . . . . . . . . . 12

REFERENCES . . . . . . . . . . . . . . . . . . . . . . . . . . . . . . . . . . . . . . 12

CHARACTERISTICS OF STUDIES . . . . . . . . . . . . . . . . . . . . . . . . . . . . . . . . . . . . .

DATA AND ANALYSES . . . . . . . . . . . . . . . . . . . . . . . . . . . . . . . . . . . . . . . . . . . 46 


\title{
[Intervention Review] \\ Support surfaces for pressure ulcer prevention
}

\author{
Nicky A Cullum ${ }^{1}$, Elizabeth McInnes ${ }^{2}$, Sally EM Bell-Syer ${ }^{1}$, Rosa Legood ${ }^{3}$ \\ ${ }^{1}$ Department of Health Sciences, University of York, York, UK. ${ }^{2}$ Haberfield, Australia. ${ }^{3}$ Health Services Research Unit, Dept of Public \\ Health \& Policy, London School of Hygiene and Tropical Medicine, London, UK \\ Contact address: Nicky A Cullum, Department of Health Sciences, University of York, Seebohm Rowntree Building, York, North \\ Yorkshire, YO10 5DD, UK. nac2@york.ac.uk.
}

Editorial group: Cochrane Wounds Group.

Publication status and date: Edited, published in Issue 3, 2008.

Review content assessed as up-to-date: 19 May 2004.

Citation: Cullum NA, McInnes E, Bell-Syer SEM, Legood R. Support surfaces for pressure ulcer prevention. Cochrane Database of Systematic Reviews 2004, Issue 3. Art. No.: CD001735. DOI: 10.1002/14651858.CD001735.pub2.

Copyright (C) 2008 The Cochrane Collaboration. Published by John Wiley \& Sons, Ltd.

\begin{abstract}
A B S T R A C T
Background

Pressure ulcers (also known as bedsores, pressure sores, decubitus ulcers) are areas of localised damage to the skin and underlying tissue due to pressure, shear or friction. They are common in the elderly and immobile and costly in financial and human terms. Pressurerelieving beds, mattresses and seat cushions are widely used as aids to prevention in both institutional and non-institutional settings.
\end{abstract}

\section{Objectives}

This systematic review seeks to answer the following questions:

to what extent do pressure-relieving cushions, beds, mattress overlays and mattress replacements reduce the incidence of pressure ulcers compared with standard support surfaces?

how effective are different pressure-relieving surfaces in preventing pressure ulcers, compared to one another?

\section{Search strategy}

The Specialised Trials Register of the Cochrane Wounds Group (compiled from regular searches of many electronic databases including MEDLINE, CINAHL and EMBASE plus hand searching of specialist journals and conference proceedings) was searched up to January 2004, Issue 4, 2003 of the Cochrane Central Register of Controlled Trials was also searched. The reference sections of included studies were searched for further trials.

\section{Selection criteria}

Randomised controlled trials (RCTs), published or unpublished, which assessed the effectiveness of beds, mattresses, mattress overlays, and seating cushions for the prevention of pressure ulcers, in any patient group, in any setting. RCTs were eligible for inclusion if they reported an objective, clinical outcome measure such as incidence and severity of new of pressure ulcers developed. Studies which only reported proxy outcome measures such as interface pressure were excluded.

\section{Data collection and analysis}

Trial data were extracted by one researcher and checked by a second. The results from each study are presented as relative risk for dichotomous variables. Where deemed appropriate, similar studies were pooled in a meta analysis.

Support surfaces for pressure ulcer prevention (Review)

Copyright $\odot 2008$ The Cochrane Collaboration. Published by John Wiley \& Sons, Ltd. 


\section{Main results}

41 RCTs were included in the review.

Foam alternatives to the standard hospital foam mattress can reduce the incidence of pressure ulcers in people at risk. The relative merits of alternating and constant low pressure devices, and of the different alternating pressure devices for pressure ulcer prevention are unclear.

Pressure-relieving overlays on the operating table have been shown to reduce postoperative pressure ulcer incidence, although one study indicated that an overlay resulted in adverse skin changes. One trial indicated that Australian standard medical sheepskins prevented pressure ulcers. There is insufficient evidence to draw conclusions on the value of seat cushions, limb protectors and various constant low pressure devices as pressure ulcer prevention strategies.

A study of Accident \& Emergency trolley overlays did not identify a reduction in pressure ulcer incidence. There are tentative indications that foot waffle heel elevators, a particular low air loss hydrotherapy mattress and an operating theatre overlay are harmful.

\section{Authors' conclusions}

In people at high risk of pressure ulcer development, consideration should be given to the use of higher specification foam mattresses rather than standard hospital foam mattresses. The relative merits of higher-tech constant low pressure and alternating pressure for prevention are unclear. Organisations might consider the use of pressure relief for high risk patients in the operating theatre, as this is associated with a reduction in post-operative incidence of pressure ulcers. Seat cushions and overlays designed for use in Accident $\&$ Emergency settings have not been adequately evaluated.

\section{PLAINLANGUAGESUMMARY}

\section{Can pressure ulcers be prevented by using different support surfaces?}

Pressure ulcers (also called bed sores) are ulcers on the skin caused by pressure or rubbing at the weight-bearing, bony points of immobilised people (such as hips, heels and elbows). Different pressure relieving surfaces (e.g. beds, mattresses, mattress overlays and cushions) are used to cushion vulnerable parts of the body and distribute the surface pressure more evenly. The review found that people lying on ordinary foam mattresses are more likely to get pressure ulcers than those on higher specification foam mattresses. More research comparing different support surfaces is needed.

\section{B A C K G R O U N D}

Pressure ulcers (also known as pressure sores, decubitus ulcers and bed sores) are areas of localised damage to the skin and underlying tissue, believed to be caused by pressure, shear or friction (Allman 1997). They usually occur over bony prominences such as the base of the spine, hips and heels. Pressure ulcers occur in both hospital and community settings, most often in the elderly and immobile (e.g. orthopaedic patients), those with severe acute illness (e.g. patients in intensive care units) and in people with neurological deficits (e.g. with spinal cord injuries).

The development of pressure ulcers is relatively common. A review of epidemiological studies in the UK, Canada and the USA describes reported pressure ulcer prevalence in the UK of be- tween $4.4 \%$ in a community unit up to $37 \%$ in palliative care (Kaltenhalter 2001). In the USA and Canada prevalence ranged from $4.7 \%$ in hospital patients to $33 \%$ in spinal cord injured patients in the community. They represent a major burden of sickness and unmeasured effects on quality of life for patients and their carers, and are costly to health care systems. In the UK the cost of preventing and treating pressure ulcers in a 600-bedded large general hospital was estimated at between $£ 600,000$ and $£ 3$ million per year (Clark 1994). The extent to which pressure ulcers are preventable is not clear.

A pressure ulcer can be defined as "a new or established area of skin and/or tissue discolouration or damage which persists after the removal of pressure and which is likely to be due to the effects of pressure on the tissues" (Dept of Health 1993). Health care 
professionals attempt to reduce the incidence of severe pressure ulcers by the identification of people at high risk and the use of prevention strategies, such as pressure-relieving equipment. It is essential that initiatives are based on the best available evidence of clinical-and cost-effectiveness and we have therefore undertaken a systematic review of the evidence for the effectiveness of pressurerelieving support surfaces such as beds, mattresses, cushions, and repositioning interventions. A systematic review of the epidemiology of pressure ulcers is outside the scope of this review.

Types of Pressure-relieving Interventions

The aim of pressure ulcer prevention strategies is to reduce the magnitude and/or duration of pressure between a patient and their support surface (the "interface pressure"). This may be achieved by regular manual repositioning (e.g. "two hourly turning”), or by using pressure-relieving support surfaces such as cushions, mattress overlays, replacement mattresses or whole bed replacements. The cost of these interventions varies widely; from over $£ 30,000$ for some bed replacements to less than $£ 100$ for some foam overlays. Information on the relative cost-effectiveness of this equipment is clearly needed to aid rational use.

Pressure-relieving cushions, beds and mattresses either mould around the shape of the patient to distribute the patient's weight over a larger area (constant low pressure devices) (CLP), or mechanically vary the pressure beneath the patient, so reducing the duration of the applied pressure (alternating pressure devices) (AP) (Bliss 1993). CLP devices (either overlays, mattresses or replacement beds) can be grouped according to their construction (foam, foam and air, foam and gel, profiled foam, hammocks, air suspension, water suspension and air-particulate suspension/air-fluidised). These devices fit or mould around the body so that the pressure is dispersed over a large area. Alternating pressure devices generate alternating high and low interface pressures between body and support, usually by alternate inflation and deflation of airfilled cells. Such devices are available as cushions, mattress overlays, and single-or multi-layer mattress replacements.

Turning beds, such as turning frames, net beds, and turning/tilting beds move those patients, either manually or automatically, who are unable to turn themselves. Pressure ulcer prevention is often not the reason for using turning and tilting beds; they may be used in Intensive and Critical Care Units for other reasons, e.g. to promote chest drainage.

\section{O B J E C T I VES}

This systematic review seeks to answer the following questions:

- to what extent do pressure-relieving cushions, beds, mattress overlays and mattress replacements reduce the incidence of pressure ulcers compared with standard support surfaces?
- how effective are different pressure-relieving surfaces in preventing pressure ulcers, compared to one another?

\section{MET HODS}

\section{Criteria for considering studies for this review}

\section{Types of studies}

Randomised controlled trials (RCTs) comparing beds, mattresses and cushions which measured the incidence of new pressure ulcers. Studies which used only subjective measures of outcome (e.g., skin condition "better" or "worse") were excluded, as were studies which reported only proxy measures such as interface pressure. There was no restriction on the basis of the language in which the study reports were written, nor publication status.

\section{Types of participants}

Patients receiving health care who were deemed to be at risk of pressure ulcer development, in any setting.

\section{Types of interventions}

Studies which evaluated the following interventions for pressure ulcer prevention were included:

\section{Low-tech surfaces:}

- Standard foam mattresses

- Alternative foam mattresses/overlays (e.g. convoluted foam, cubed foam): these are conformable and aim to redistribute pressure over a larger contact area

- Gel-filled mattresses/overlays: mode of action as above

- Fibre-filled mattresses/overlays: mode of action as above

- Air filled mattresses/overlays: mode of action as above

- Water-filled mattresses/overlays: mode of action as above

- Bead filled mattresses/overlays: mode of action as above

- Sheepskins: proposed mode of action unclear.

\section{High-tech surfaces:}

- Alternating pressure mattresses/overlays: Patient lies on air filled sacs which sequentially inflate and deflate and relieve pressure at different anatomical sites for short periods; may incorporate a pressure sensor.

- Air fluidised beds: warmed air circulated through fine ceramic beads covered by a permeable sheet; allows support over a larger contact area.

- Low air loss beds: patients are supported on a series of air sacs through which warmed air passes.

Other surfaces: 
- Turning beds/frames: these work by either aiding manual repositioning of the patient, or by motor driven turning and tilting.

- Wheelchair cushions: may be conforming and therefore reduce contact pressures by increasing surface area in contact, or mechanical e.g. alternating pressure.

- Operating table overlays: as above.

- Limb protectors: pads and cushions of different forms to protect bony prominences.

\section{Types of outcome measures}

\section{Primary outcomes}

1. Incidence of new pressure ulcers.

Many evaluations have simply measured the pressure on different parts of the body in contact with the support surface (interface pressure). However, interface pressure is an intermediate or surrogate outcome measure which has serious limitations as a proxy for clinical outcome, since the process which leads to the development of a pressure ulcer almost certainly involves the complex interplay of several factors. Unfortunately, because it is relatively simple, quick and inexpensive to measure, most evaluations only compare interface pressure. In this review we have only considered trials which report the clinical outcome measure of pressure ulcer incidence.

Some studies, when reporting outcomes of interventions for prevention, did not differentiate between people developing grade 1 ulcers (in which the skin is unbroken) and those developing more severe ulcers. Studies which compare the incidence of pressure ulcers of grade 2 or greater are more likely to be reliable (see below for details of grading system), however we included all studies irrespective of whether grade 1 ulcers were described separately.

2. Grades of new pressure ulcers.

A range of pressure ulcer grading systems is used in pressure ulcer trials. An example of a commonly used grading system is presented below:

GRADE 1: Persistent discolouration of the skin including nonblanchable erythema; blue/purple/black discolouration.

GRADE 2: Partial thickness skin loss involving epidermis and dermis.

GRADE 3: Full thickness skin loss involving damage or necrosis of subcutaneous tissues but not through the underlying fascia and not extending to the underlying bone, tendon or joint capsule. GRADE 4: Full thickness skin loss with extensive destruction and tissue necrosis extending to the underlying bone, tendon or joint capsule.

\section{Secondary outcomes}

the following outcomes were also recorded where available:

- Costs of the devices
- Patient comfort

- Durability of the devices

- Reliability of the devices

- Acceptability of the devices

\section{Search methods for identification of studies}

\section{Electronic searches}

The Wounds Group Specialised Trials Register was searched up to January 2004, this register is maintained by regular searching of the following databases: CENTRAL, MEDLINE, EMBASE and CINAHL and hand searching conference proceedings. The Cochrane Central Register of Controlled Trials (CENTRAL) was searched, Issue 42003 using the following strategy:

1. BEDS single term $(\mathrm{MeSH})$

2. (bed or beds or bedding)

3. mattress*

4. cushion*

5. foam or transfoam

6. overlay*

7. (pad or pads)

8. gel

9. (pressure near relie*)

10. (pressure near device*)

11. (pressure near reduction)

12. (pressure near reducing)

13. (positioning* or repositioning*)

14. ((low next pressure) and support $\left.{ }^{*}\right)$

15. ((low next pressure) and device*)

16. (constant near pressure)

17. (alternat* near pressure)

18. (air near suspension*)

19. (water near suspension*)

20. clinifloat

21. vaperm

22. therarest

23. maxifloat

24. sheepskin*

25. hammock*

26. (foot next waffle)

27. silicore

28. pegasus

29. (cairwave near therapy)

30. (turning near table*)

31. (kinetic near table*)

32. (kinetic near therapy)

33. (air next bag*)

34. (elevation near device*)

35. (static next air)

36. (\#1 or \#2 or \#3 or \#4 or \#5 or \#6 or \#7 or \#8 or \#9 or \#10)

Support surfaces for pressure ulcer prevention (Review)

Copyright @ 2008 The Cochrane Collaboration. Published by John Wiley \& Sons, Ltd. 
37. (\#11 or \#12 or \#13 or \#14 or \#15 or \#16 or \#17 or \#18 or \# 19 or \#20)

38. (\#21 or \#22 or \#23 or \#24 or \#25 or \#26 or \#27 or \#28 or \# 29 or \#30)

39. (\#31 or \#32 or \#33 or \#34 or \#35)

40. (\#36 or \#37 or \#38 or \#39)

41. DECUBITUS ULCER single term $(\mathrm{MeSH})$

42. (decubitus next ulcer*)

43. (bed near ulcer*)

44. (bed near sore*)

45. (pressure near sore*)

46. (pressure near ulcer*)

47. (\#41 or \#42 or \#43 or \#44 or \#45 or \#46)

48. (\#40 and \#47)

\section{Searching other resources}

Experts in the field of wound care were originally contacted to enquire about ongoing and recently published trials in the field of wound care. In addition, manufacturers of wound care materials were contacted for details of the trials they are conducting. This process has not been repeated for this update. Citations within obtained reviews and papers were scrutinised to identify additional studies. There was no restriction on the basis of the language in which the study reports were written, nor publication status.

\section{Data collection and analysis}

\section{Selection of studies}

For this update the titles and abstracts of the search results were assessed for relevance by two reviewers (EMcI, SB-S), full copies of all potentially relevant studies were obtained. Decisions on final inclusion after retrieval of full papers was made by one reviewer (EMcI) and checked by a second reviewer (RL); disagreements were resolved by discussion with a third reviewer (NC or SB-S). Rejected studies were checked by a third reviewer (one of SB-S; NC).

\section{Selection of studies}

For this update the titles and abstracts of the search results were assessed for relevance by two reviewers (EMcI, SB-S), full copies of all potentially relevant studies were obtained. Decisions on final inclusion after retrieval of full papers was made by one reviewer (EMcI) and checked by a second reviewer (RL); disagreements were resolved by discussion with a third reviewer (NC or SB-S). Rejected studies were checked by a third reviewer (one of SB-S; NC).

\section{Data extraction and management}

Data from included trials were extracted by a single reviewer into pre-prepared data extraction tables and checked by a second reviewer. The following data were extracted from each study:

- patient inclusion/exclusion criteria

- care setting

- key baseline variables by group e.g. age, sex, baseline risk, baseline area of existing ulcers

- description of the interventions and numbers of patients randomised to each intervention

- description of any co-interventions/standard care

- duration and extent of follow up

- outcomes (incidence and severity of new pressure ulcers)

- acceptability and reliability of equipment if reported

\section{Assessment of risk of bias in included studies}

The methodological and reporting quality of each trial were assessed by a single reviewer and checked by a second reviewer. The following quality criteria were used:

- description of inclusion and exclusion criteria used to derive the sample from the target population

- description of a priori sample size calculation

- evidence of allocation concealment at randomisation

- description of baseline comparability of intervention groups

- outcome assessment stated to be blinded

- incident ulcers described by severity grading as well as frequency (Grade 1 ulcers are not breaks in the skin and are subject to more inter-rater variation)

- clear description of main interventions.

\section{Dealing with missing data}

Where study details or data were missing from reports then attempts were made to contact the authors to complete the information necessary. If studies were published more than once, the most detailed report was used as the basis of the data extraction.

\section{Data synthesis}

For each trial, relative risk (RR) was calculated for categorical outcomes such as number of patients developing ulcers. $95 \%$ confidence intervals $(95 \% \mathrm{CI})$ were included when sufficient detail to allow their calculation was provided. The results from replicated studies were plotted on to graphs and discussed by narrative review. Unique comparisons were not plotted and the relative risk is stated in the text. Individual study details are presented in structured tables (See Characteristics of Included Studies Table). Where there was more than one trial comparing similar devices using the same outcome (though possibly differing lengths of follow up), statistical heterogeneity was tested for by $\mathrm{I}^{2}$ (Higgins 2003). In the absence of significant statistical heterogeneity, studies with 
similar comparisons were pooled using a fixed effects model. If heterogeneity was observed both random and fixed effects models were used to pool the data. For the purpose of meta analysis we assumed that relative risk remained constant for different lengths of follow up , hence we pooled studies which followed participants for different lengths of time. All statistical analysis was performed on RevMan (4.2.3).

\section{RE S U L T S}

\section{Description of studies}

See: Characteristics of included studies; Characteristics of excluded studies.

Forty-one relevant randomised clinical trials were identified (See Characteristics of Included Studies Table). Twenty-one trials involved patients without pre-existing pressure ulcers (intact skin); 4 included patients with ulcers greater than stage $1 ; 3$ included both patients with and without ulcers and in 13 studies the baseline skin status of the participants was unclear.

Study Settings

Four studies evaluated different operating table surfaces ( Aronovitch 1999; Nixon 1998; Russell 2000; Schultz 1999); six evaluated different surfaces in intensive care units (ICU) (Gentilello 1988; Inman 1993; Laurent 1997; Sideranko 1992; Summer 1989; Takala 1996); eight studies confined their evaluation to orthopaedic patients (Cooper 1998; Exton-Smith 1982; Goldstone 1982; Hofman 1994; McGowan 2000; Price 1999; Santy 1994; Stapleton 1986) and one involved an accident and emergency department setting (Gunningberg 2000). The remaining studies looked at a variety of patients, for example those in nursing homes $(\mathrm{n}=8)$ and those on care of the elderly, medical and surgical wards.

Three trials evaluated cushions, two evaluated the use of sheepskins, and three looked at turning beds/kinetic therapy. The remaining studies evaluated different mattresses, overlays and beds.

\section{Risk of bias in included studies}

A summary of the sample size and methodological quality of each trial is shown in Table 1.

Although the majority of trials discussed the criteria for including patients, only approximately $50 \%$ of the reports gave information that indicated that patients were randomly allocated with concealed allocation.

Blinded outcome assessment is rarely used in wound care studies and this was certainly the case in these evaluations of pressure relieving surfaces. It can be difficult or impossible to disguise the surface that a patient is on for assessment of outcome, and patients are often too ill to be removed from their bed for assessment of their pressure areas. Nevertheless, some studies minimise bias in outcome assessment by having a second assessor and presenting inter-rater reliability data, or by presenting photographic evidence of pressure area status which can then be assessed by an assessor blinded to treatment. Of the 41 RCTs in this review, we could be confident that blinded outcome assessment had been used in only 10 trials.

Small sample size was a major limitation of many of the studies; the median sample size was 80 (range 12 to 1166 ) and only 14 studies described an a priori sample size estimate. High attrition rates and lack of an intention-to-treat analysis were also common. For most comparisons there is a lack of replication.

In studies of pressure ulcer prevention it is extremely important for trialists to report on the baseline comparability of the intervention groups for important variables such as baseline risk. Risk of pressure ulcer development is usually reported as one of various risk scores such as Norton, Waterlow, Gosnell or Braden. Some of the studies reviewed here did not present such baseline data.

\section{Effects of interventions}

HOW THE RESULTS ARE PRESENTED AND WHAT THE TERMS MEAN

Results of dichotomous variables are presented as relative risk (RR) with $95 \%$ confidence intervals (CI). Relative risk has been used rather than odds ratios as event rates are high in these trials and odds ratios would give an inflated impression of the magnitude of effect (Deeks 1998). Relative risk is the pressure ulcer incidence rate in the experimental group divided by the incidence rate in the control group and indicates the likelihood of pressure ulcer development on an experimental bed compared with a comparison bed. As by definition, the risk of an ulcer developing in the control group is 1 , then the relative risk reduction associated with using the experimental bed is 1-RR. The relative risk indicates the relative benefit of a therapy but not the actual benefit, i.e. it does not take into account the number of people who would have developed an ulcer anyway. The absolute risk reduction (ARR) can be calculated by subtracting the incidence rate in the experimental group from the incidence rate in the control group. The ARR tells us how much the reduction is due to the bed itself, and its inverse is the number needed to treat, or NNT. Thus an incidence rate of $30 \%$ on a control mattress reduced to $15 \%$ with an experimental mattress translates into an ARR of $30-15=15 \%$ or 0.15 , and an NNT of 7 , in other words 7 patients would need to receive the experimental mattress to prevent the development of one additional pressure ulcer.

Methods for measuring secondary outcomes such as comfort, durability, reliability and acceptability were not well developed. 
Where data was presented it appears in the Characteristics of Included Studies Table, but not incorporated in the analysis.

\section{'Low-tech' constant pressure supports}

This section considers comparisons of standard foam hospital mattresses with other low-technology (low-tech), constant low pressure supports (CLP). We regarded the following as low-tech CLP: sheepskin, static air-filled supports; water-filled supports; contoured or textured foam supports; gel-filled supports; bead-filled supports; Silicore-filled supports. It should be emphasised however that there is no international definition of what constitutes a standard foam hospital mattress and indeed this changes over time within countries and even within hospitals. Where a description of the standard was provided it is included in the Characteristics of Included Studies Table. We have assumed that standard mattresses are likely to vary less within than between countries and undertaken subgroup analysis by country, however this was not pre-specified.

\section{Standard foam hospital mattress compared with other low- tech CLP.}

Seven RCTs compared 'standard' mattresses/surfaces with 'lowtech' supports for the prevention of pressure ulcers (Andersen 1982; Collier 1996; Goldstone 1982; Gray \& Campbell 1994; Hofman 1994; Russell 2002; Santy 1994).

When compared with standard hospital mattresses, the incidence and severity of pressure ulcers in 'high risk' patients were reduced when patients were placed on either the Comfortex DeCube mattress (Hofman 1994) (RR 0.34, 95\% CI 0.14 to 0.85); the Beaufort bead bed (Goldstone 1982) (RR 0.32, 95\% CI 0.14 to 0.76 ); the Softform mattress (Gray \& Campbell 1994) (RR 0.2, 95\% CI 0.09 to 0.45 ); or the water-filled mattress (Andersen 1982) (RR $0.35,95 \%$ CI 0.15 to 0.79 ). In an unpublished British study of older people with hip fractures admitted to orthopaedic trauma wards, patients allocated to receive a NHS standard foam mattress (manufactured by Relyon) experienced over three times the rate of pressure ulcers as those using one of a number of foam alternatives (Clinifloat, Therarest, Transfoam and Vaperm) (Santy 1994) (RR $0.36,95 \%$ CI 0.22 to 0.59 ). Another study, found a significant decrease in the incidence of grade I pressure ulcers from $26.3 \%$ to $19.9 \%(\mathrm{p}=0.0004)$ and a non-significant decrease in the incidence of pressure ulcers grade II to IV from $10.9 \%$ to $8.5 \%$ in patients allocated to the high-specification foam mattress/cushion (RR 0.73; CI 0.59 to 0.91 ) (Russell 2002). No patient developed a pressure ulcer in the Collier 1996 trial. The comparisons were considered too heterogeneous to pool these 7 studies (Analysis 1.1).

The five trials comparing foam alternatives with the standard hospital foam mattress (Collier 1996; Gray \& Campbell 1994; Hofman 1994; Santy 1994; Russell 2002) were pooled using a random effects model $\left(\mathrm{I}^{2}=77 \%\right)$. These trials were of mixed quality; they all provided evidence of allocation concealment but none used blinded outcome assessment. To avoid double counting, the control patients in the trials with more than 2 comparisons, and in the absence of major differences between the effects of different foams, the foam alternatives were pooled. This approach maintains the randomisation but results in comparison groups of unequal size. This analysis yielded a pooled relative risk of 0.40 (95\% CI 0.21 to 0.74 ), or a relative reduction in pressure ulcer incidence of $60 \%$ (95\% CI 26\% to 79\%)(Analysis 2.1). Concern regarding the heterogeneity in standard hospital mattress between these trials led us to undertake a separate meta analysis of UK based studies (where variation in the standard hospital mattress is likely to be less). Pooling the 4 studies which compared alternative foam supports with standard foam mattresses in the UK (Collier 1996; Gray \& Campbell 1994; Russell 2002; Santy 1994) resulted in the significant benefit of alternative foam over standard foam being maintained (RR 0.41, 95\%CI 0.19 to 0.87) (Analysis 2.2). Therefore foam alternatives to the standard hospital mattress can reduce the incidence of pressure ulcers in at risk patients, including patients with fractured neck of femur.

\section{Comparisons between Alternative foam mattresses}

This section covers results of studies which performed head-tohead comparisons of high-specification foam products (i.e. contoured foam, supports comprising foam of different densities). Five RCTs (Collier 1996; Gray \& Smith 1994; Kemp 1993; Santy 1994; Vyhlidal 1997) compared different foam alternatives. (Analysis 3.1)

Santy 1994 and colleagues compared 5 alternative foam mattresses (Clinifloat, Vaperm, Therarest, Transfoam, NHS standard foam) and found significant reductions in pressure ulcer incidence associated with Clinifloat, Therarest, Vaperm and Transfoam compared with standard. Vyhlidal 1997 and colleagues compared a 4 inch thick foam overlay (Iris 3000) with a foam and fibre mattress replacement (Maxifloat) and reported a significant reduction in pressure ulcer incidence (RR 0.42 , 95\% CI 0.18 to 0.96 ) with the mattress replacement, however this trial appeared to have used neither allocation concealment nor blinded outcome assessment. The RR translates to a relative reduction in the incidence of pressure ulcers of $58 \%$ associated with use of the 5 -section foam and fibre mattress replacement (an ARR of 0.35 , or $35 \%$ and an NNT of 3 , or one additional pressure ulcer prevented for every 3 patients receiving a Maxifloat mattress replacement).

No patient developed a pressure ulcer in the Collier 1996 trial. Kemp 1993 compared a convoluted foam overlay with a solid foam overlay in only 84 patients and found no significant difference in pressure ulcer incidence rates however this may be a Type 2 error, in other words the small sample size may have precluded detection of a significant difference. Gray \& Smith 1994 compared the Transfoam and Transfoamwave foam mattresses however only 1 patient in each group developed a ulcer. 


\section{Comparisons between 'Low-tech' Constant Low Pressure Supports:}

This section covers head-to-head comparisons of the following types of support: foams; static air-filled supports (including dry flotation); water-filled supports; gel-filled supports; Silicore-filled supports; heel elevators and sheepskins (Analysis 4.1).

Eight RCTs have compared different low-tech CLP devices for prevention (Cooper 1998; Ewing 1964; Lazzara 1991; McGowan 2000; Sideranko 1992; Stapleton 1986; Takala 1996; Tymec 1997). Most of these trials are underpowered and/or have other methodological flaws.

A trial from Finland (Takala 1996) comparing the Optima (Carital) constant low pressure mattress - which comprises 21 double air bags on a base - with the standard hospital mattress found that $37 \%$ of patients on the standard mattress developed ulcers compared with none on the Optima (RR 0.06; 95\% CI 0 to 0.99). The report of this study did not describe either allocation concealment or blinded outcome assessment.

One trial compared a proprietary heel elevation device (Foot Waffle) comprising a vinyl boot with built in foot cradle, with elevation of the heels using a hospital pillow (Tymec 1997). More heel ulcers developed in the group using the Foot Waffle (6 vs 2) although this difference was not statistically significant (the trial involved only 52 patients).

The remaining trials were all unique comparisons with low power and none found statistically significant differences between the surfaces tested.

Two trials have examined the effects of sheepskins on pressure ulcer incidence. The first (Ewing 1964) comparing the standard hospital mattress with and without sheepskin overlays, was considered too small and poorly designed to detect a difference. The second involving 297 orthopaedic patients (McGowan 2000) found that pressure ulcer incidence was significantly reduced in those assigned an Australian medical sheepskin ( $R R$ for sheepskins relative to standard treatment was 0.30 (95\%CI 0.17 to 0.52$)$ (Analysis 4.1).

\section{'High-tech' pressure relief}

\section{Alternating Pressure Supports:}

A variety of alternating pressure (AP) supports is used in hospital and community. The depth of the air-cells and the mechanical robustness vary between devices and these factors may be important in determining effectiveness. It is worth emphasising that most of the RCTs of AP supports did not adequately describe the equipment being evaluated, including the size of the air cells.

Eleven RCTs of alternating pressure supports for pressure ulcer prevention were identified: these compared AP and standard hospital mattresses in one study (Andersen 1982); AP and various constant low pressure devices in eight studies such as water (Andersen 1982; Sideranko 1992), static air (Sideranko 1992;
Price 1999), Silicore (Conine 1990; Daechsel 1985; Sideranko 1992), foam (Sideranko 1992; Whitney 1984), various (Gebhardt 1994; Laurent 1997); and with other alternating pressure supports in 3 studies (Exton-Smith 1982; Hampton 1997; Taylor 1999).

\section{Alternating Pressure Compared With Standard Hospital Mattress}

One RCT (Andersen 1982) reported that the use of alternating pressure surfaces reduces the incidence of pressure ulcers compared with standard hospital mattresses (RR 0.32 , 95\% CI 0.14 to 0.74 ). This report of this large trial, involving 482 patients at 'high-risk' of pressure ulcers, gave no indication that either allocation concealment or blinded outcome assessment had been used. (Analysis 5.1)

\section{Alternating Pressure Compared With Constant Low Pressure}

Eight trials compared alternating pressure devices with various constant low pressure devices, however there is conflicting evidence as to their relative effectiveness. One study compared a range of AP supports with a range of CLP supports in a range of specialties in acute care settings (Gebhardt 1994) and reported significantly more pressure ulcers in patients in the CLP group (34\% compared with $13 \%$ in the AP group) (RR $0.38,95 \%$ CI 0.22 to 0.66 )(Analysis 6.1). This trial is difficult to interpret given the wide variety of surfaces used within the study - there is currently insufficient evidence to support a 'class effect' for all alternating pressure devices and all constant low pressure devices.

In contrast, seven small RCTs comparing different types of alternating pressure supports and a variety of constant low pressure devices such as the Silicore overlay (Conine 1990; Daechsel 1985; Stapleton 1986), a water mattress (Andersen 1982; Sideranko 1992), a foam pad (Stapleton 1986; Whitney 1984), and static air mattresses (Price 1999; Sideranko 1992) individually reported no difference in effectiveness, although many were too small to be able to detect clinically important differences as statistically significant. Four studies which compared AP with Silicore or foam overlays were pooled (Conine 1990; Daechsel 1985; Stapleton 1986; Whitney 1984). To avoid double counting of the patients in the AP arm of the Stapleton 3-arm trial, and in the absence of obvious heterogeneity in the outcomes for Silicore and foam, the Silicore and foam arms were pooled against the AP arm (maintaining the randomisation, avoiding double counting, but resulting in unequal comparison groups). Overall the pooled relative risk of pressure ulcer development for AP v Silicore or foam overlays (using a fixed effects model; $\mathrm{I}^{2}=0 \%$ ) was 0.91 , (95\% CI 0.71 to 1.17 ) indicating no statistically significant difference between Silicore or foam overlays and AP. (Analysis 6.1)

The studies which compared AP with static water or static air mattresses were similarly considered together (Andersen 1982; Price 1999; Sideranko 1992). The Sideranko trial also had 3 comparison groups and for the purposes of the meta-analysis, the water 
and static air arms of this study were considered sufficiently similar to pool together against AP to avoid double counting of the AP patients. Pooling these three trials to answer the question of whether AP is associated with fewer incident ulcers than air or water filled mattresses using a random effects model $\left(\mathrm{I}^{2}=25 \%\right)$ yielded a pooled RR of 1.26 (95\% CI 0.6 to 2.61 ) indicating no statistically significant difference (Analysis 6.3).

It is worth emphasising, however, that all these studies were small, and, even when pooled were too underpowered to detect clinically important differences in effectiveness as statistically significant.

All eight RCTs comparing the various CLP devices and AP devices were pooled to try to answer the question of whether AP is more effective than CLP in pressure ulcer prevention. Double counting was avoided for the Sideranko and Stapleton trials as before. In view of the different devices evaluated in the studies, the $\mathrm{I}^{2}$ of $45.3 \%$ and the Chi-square of $12.81(\mathrm{df}=7)$, a random effects model was applied. This yielded an overall relative risk of $0.82(95 \%$ CI 0.57 to 1.19 ) suggesting no statistically significant difference between the rates of pressure ulcer incidence on AP versus CLP (Analysis 6.1). Further trials are needed to determine whether the CLP and AP devices are associated with a clinically important difference in risk of pressure ulceration.

Finally one trial used a complex factorial design to compare various combinations of standard, constant low pressure and alternating pressure support in surgical intensive care patients intra- and postICU. This trial (which involved only 75 to 80 patients in each group) did not identify any significant benefit associated with using alternating pressure in the ICU (Laurent 1997) (Analysis 7.1).

\section{Comparisons between Different Alternating Pressure Devices}

Alternating pressure devices differ somewhat in structure, e.g., the size of the inflatable air cells. One early study of pressure ulcer prevention (Exton-Smith 1982) compared two large-celled alternating pressure devices (Pegasus Airwave and the Large Cell Ripple - similar except the Airwave has two layers of cells). The authors reported that the Airwave System was significantly more effective than the Large Cell Ripple in preventing and reducing severity of pressure ulcers in a high risk group of elderly patients. However, the allocation was not truly random, and an intention-to-treat analysis would not have shown a statistically significant difference in the rate of pressure ulcers ( $16 \%$ vs $34 \%, \mathrm{P}>0.05)$.

Hampton 1997 compared the Pegasus Airwave mattress with a new Cairwave Therapy system by the same manufacturer, in 75 patients. No patients developed an ulcer in either arm of this study. More recently, Taylor 1999 compared the Pegasus Trinova 3-cell alternating pressure air mattress combined with a pressure redistributing cushion (intervention) with a 2 -cell alternating pressure air mattress combined with a pressure redistributing cushion (control). This study was underpowered to detect important differences ( 22 patients in each group) and whilst two patients developed a superficial ulcer in the control group and none in the other, this difference was not statistically significant (Analysis 8.1).

\section{Low Air-Loss Beds}

One trial showed that low air-loss beds were more cost-effective at decreasing the incidence of pressure ulcers in critically ill patients than a standard (but poorly described) ICU bed (RR 0.24, 95\% CI 0.11 to 0.53) (Inman 1993) (Graph:Comparison 9, Outcome 2). A second trial compared low air loss hydrotherapy (LAL-hydro) with standard care (some patients received alternating pressure in this group); more patients developed ulcers of grade 2 ulcer greater in the LAL-hydro group (19\%) than the standard care group (7\%) though this did not reach significance (the trial involved only 98 patients) (Bennett 1998) (Analysis 9.1).

\section{Air Fluidised Beds compared with Dry Flotation}

One small trial in patients after plastic surgical repair of pressure ulcers showed no difference between an air-fluidised bed and the Roho dry flotation mattress in post-operative tissue breakdown rates (Economides 1995) (Analysis 10.1).

\section{Other interventions}

\section{Kinetic Turning Tables}

Turning beds contain motors which constantly turn and tilt the patient, and are used in critical care settings primarily to prevent pneumonia and atelectasis. Four RCTs were identified in a metaanalysis of kinetic therapy (Choi 1992) however full copies of only two of the individual trials could be obtained for this systematic review (Gentilello 1988; Summer 1989). Sample sizes in all the trials was small, and no beneficial effect of kinetic therapy on pressure ulcer incidence was detected (Analysis 11.1).

\section{Profiling Beds}

A recent trial (Keogh \& Dealey 2001) with 35 patients in each arm found no pressure ulcers developed in either the group assigned the profiling bed with a pressure reducing foam mattress/cushion combination nor the group assigned a flat-based bed with a pressure-relieving/redistributing foam mattress/cushion combination.

\section{Operating Table Overlays}

Four RCTs have evaluated different methods of pressure relief on the operating table. The first compared a visco-elastic polymer pad with a standard table and found a relative reduction in the incidence of post-operative pressure ulcers of $47 \%$ associated with using the polymer pad for patients undergoing elective major general, gynaecological or vascular surgery (supine or lithotomy) (RR 0.53; $95 \%$ CI 0.33 to 0.85 ) (Nixon 1998) (Analysis 12.1). 
Two further RCTs have compared the Micropulse alternating system (applied both during surgery and post-operatively) with a gel pad during surgery and standard mattress post-operatively. We pooled these two trials $\left(\mathrm{I}^{2}=0\right)$ and derived a pooled relative risk (fixed effects) of 0.21 , (95\% CI 0.06 to 0.7 ) in favour of the Micropulse system (Aronovitch 1999; Russell 2000). It is not clear from these 2 trials whether the effect is due to the intra-operative or the post-operative pressure relief, or both (Analysis 13.1).

Finally a trial compared a mattress operating theatre overlay with usual care (which included padding as required, for example gel pads, foam mattresses) (Schultz 1999). People in the overlay group were more likely to experience postoperative skin changes, and six patients in the overlay group developed ulcers of stage II or more compared with 3 people with ulcers of stage II or more in the control group. No attempt was made to gather information on postoperative skin care of the patient. Details regarding stage of ulcer by group and of the unnamed product are currently being sought from the authors. In the absence of this information, the clinical importance of the findings is difficult to assess.

\section{Overlay used on Accident \& Emergency trolleys}

Gunningberg 2000 examined the effects of a viscoelastic foam trolley mattress overlay on 101 patients with a suspected hip fracture. No difference in pressure ulcer incidence was found between those assigned a visco-elastic foam mattress on arrival in A\&E followed by a viscoelastic-foam overlay on the standard ward mattress and those assigned a standard trolley mattress and ward mattress. The number of people developing a Grade II to IV ulcer was lower in the intervention group (4/48) than the control group (8/53), but this was not statistically significant.

\section{Seat Cushions}

There have been three RCTs comparing different types of seating cushion for preventing pressure ulcers; one study compared slab foam with bespoke contoured foam and found no difference (RR 1.06, 95\% CI 0.75 to 1.49 ) ( $\operatorname{Lim} 1988)$. The second study ( Conine 1994) compared the Jay gel and foam wheelchair cushion with a foam cushion in 141 patients and found fewer ulcers in the Jay cushion group, though this did not reach statistical significance (RR 0.61, 95\% CI 0.37 to 1.00). The third study (Conine 1993) found no difference in pressure ulcer incidence between those assigned a slab foam cushion bevelled at the base and those assigned a contoured foam cushion with a posterior cut out (Analysis 14.1).

\section{Summary of Results}

Foam alternatives to the standard hospital foam mattress can reduce the incidence of pressure ulcers in people at risk.

The relative merits of alternating and constant low pressure devices, and of the different alternating pressure devices for pressure ulcer prevention are unclear.
Pressure-relieving overlays on the operating table and in the postoperative period have been shown to reduce the postoperative pressure ulcer incidence, although there is some evidence that certain OR overlays may result in post-operative skin changes

There is insufficient evidence to conclude on the value of seat cushions, various constant low pressure devices and A\&E trolley overlays as pressure ulcer prevention strategies.

There are promising results from one trial investigating the effectiveness of a specific sheepskin product in preventing pressure ulcers but this study requires replication with a larger sample size using a similar product.

\section{DISCUSSION}

The confidence with which we can draw firm conclusions from the studies detailed in this review is greatly tempered by (a) the poor quality of many of the trials and (b) the lack of replication of most comparisons. The clearest conclusion one can draw is that standard hospital mattresses have been consistently outperformed by a range of foam-based, low pressure mattresses and overlays, and also by 'higher-tech' pressure-relieving beds and mattresses in the prevention of pressure ulcers. The application of this conclusion to current clinical practice is however hampered by the fact that the "standard" was poorly described in many of these studies, and what is standard varies by hospital, country and over time. This factor leads to major difficulties in interpretation of trial results and the importance of clear descriptions of all interventions in future studies cannot be overemphasised. In view of this and because we thought there would be less variation within a country, a subgroup analysis of UK based studies was undertaken, the advantage of alternative foam was maintained. Further, the effects of using alternative foam mattresses are noteworthy in their consistency.

None of the trials reviewed provided convincing reassurance that manual repositioning was provided equally to each group of participants. This is a possible confounder as care providers were not blinded to treatment allocation in any of the trials, and may have moved patients in one group more frequently if they perceived a particular mattress to be less effective. As experimental evidence of the effectiveness of manual repositioning is lacking it is difficult to say what impact this has.

The results of 3 of the 4 trials evaluating the use of pressure-relieving overlays on the operating table suggest that these are beneficial in reducing subsequent pressure ulcer incidence in high risk surgical patients. These 3 trials were of reasonable or good quality; the Nixon trial particularly was adequately powered with allocation concealment and blinded outcome assessment, lending further weight to the result. At present, the most effective means of pressure relief on the operating table is unclear; Nixon and colleagues found a gel-filled overlay to be significantly better than a 
standard operating table, whilst a gel-filled overlay on the operating table was less effective than an alternating pressure overlay intra- and post-operatively (the Micropulse system) in the other 2 trials. The Micropulse trials are confounded by their provision of a standard mattress post-operatively in the gel overlay arm, and an alternating pressure overlay post-operatively in the Micropulse arm. Thus whilst there is clearly a reduction in pressure ulcer incidence associated with the alternating pressure system, it is not clear whether this is merely a result of better postoperative pressure relief. A fourth trial (Schultz 1999) showed that post-operative skin changes occurred as a result of a particular operating theatre overlay but the clinical importance of this is difficult to ascertain the absence of further details on the results and products.

One study suggests that low air-loss beds are more effective than standard foam ICU beds in preventing pressure ulcers for people in ICU beds, however the ICU bed was not described. There are no studies comparing low air-loss therapy with alternating pressure surfaces and other 'high tech' low pressure supports.

Water-filled and bead-filled mattresses were both associated with reductions in the incidence of pressure ulcers compared with standard hospital mattresses, in trials published in the early 1980s. However, the particular products evaluated are no longer available.

There are tentative indications that three interventions may be harmful. Firstly, Foot Waffle heel elevators were associated with a trebling in the incidence of pressure ulcers that did not reach statistical significance due to the small sample size of the study. Secondly low air loss hydrotherapy which was evaluated in a trial in which 19\% LAL-hydro patients developed ulcers compared with $7 \%$ of standard care patients - again not a statistically significant difference possibly as a result of the small size of the trial (98 patients in total).

Lastly, Schultz 1999 investigated the effectiveness of an alternative foam overlay used in the operating theatre. Results suggest that patients placed on the intervention devices were significantly more likely to experience postoperative skin changes (i.e. mainly Stage 1 pressure ulcers). However, it is difficult to separate out the role of postoperative care and padding which was used as a concomitant intervention, either of which may have caused the skin changes (mainly found on buttock and coccyx). Further information on the study and product are being requested from the author by the Cochrane Wounds Group.

Few comparisons have been replicated, and as most of the trials undertaken are under-powered there is little information from which to draw conclusions. For example, air fluidised therapy as a prevention strategy has only been compared with dry flotation, and low air loss only with standard care, in one trial, as an intervention. There are clearly many gaps in the knowledge base and a rational research agenda could be developed. It is always important to consider publication bias and its potential influence on the population of studies on a topic. Whilst equipment manufac- turers appear to have contributed funding to many of the trials identified, it is difficult to see what the impact of this has been. For example, whilst bias in favour of positive results cannot be discounted, most of the studies published did not find a statistically significant difference.

Common methodological flaws include open randomisation, lack of baseline comparability, high attrition rates, lack of intention to treat analysis, lack of blind outcome assessment, further reduce the confidence with which we can regard many of the individual study findings.

Future trials should address these deficiencies and collect data on aspects of equipment performance such as reliability. It is hoped that future studies will be reported in line with current international standards for trial reporting (Moher 2001).

\section{AUTHORS' CONCLUSIONS}

\section{Implications for practice}

In people at high risk of pressure ulcer development, consideration should be given to the use of higher specification foam mattresses rather than standard hospital foam mattresses. Organisations should consider the use of pressure relief for high risk patients in the operating theatre, as this is associated with a reduction in post-operative incidence of pressure ulcers. Medical grade sheepskins were associated with a decrease in pressure ulcer development in one study.

The relative merits of higher-tech constant low pressure and alternating pressure for prevention are unclear. Seat cushions have not been adequately evaluated.

\section{Implications for research}

Independent, well-designed, multicentre RCTs are needed to compare the clinical and cost-effectiveness of different types of pressure-relieving devices for patients at different levels of risk in a variety of settings. Particular gaps, include comparisons of:

1. alternating pressure devices with other 'high-tech' equipment (such as low air-loss and air-fluidised beds) for prevention in very high risk groups

2. alternating pressure mattresses with less costly alternating pressure overlays

3. alternating pressure devices with lower tech alternatives (such as different types of high specification foam mattresses and other constant low pressure devices).

The evaluation of alternating pressure devices is given emphasis as they are viewed as standard preventive interventions in some areas and not others and may vary widely in cost (from less than $£ 1,000$ to more than $£ 4,000)$. 
The promising results arising from the RCT of Australian Medical Sheepskins require confirmation in other studies.

Research is needed into valid and reliable methods of detecting early skin damage that is prognostic of pressure ulcer development, and of the impact of pressure ulcers on quality of life. Future research must address the methodological deficiencies associated with much of the research described in this review.

Patients should be truly randomised (with concealed allocation), trials should be of sufficient size to detect clinically important differences, and have clear criteria for measuring outcomes which ideally should be assessed without knowledge of the intervention received (blinded). Interventions under evaluation should be thoroughly and clearly described. Researchers should be encouraged to develop measures to assess patient experiences of pressure-relieving equipment e.g. comfort. The studies should also have adequate follow-up and appropriate statistical analysis. The CONSORT statement (Moher 2001) should be used as a guideline for reporting.

Given the high costs associated with the prevention of pressure ulcers generally, and of pressure-relieving surfaces specifically, greater emphasis should be given to robust economic evaluations in the future.

\section{ACKNOW LEDGEMENTS}

The original review was commissioned by the NHS HTA Programme (Cullum 2001). The authors are indebted to Julie Glanville, Centre for Reviews and Dissemination Information Service, for early assistance with the search, location and collection of the literature; to Trevor Sheldon, Alison Fletcher, Fujian Song and Jon Deeks who participated in early versions of this review. The updated review Support surfaces for pressure ulcer prevention was prepared by Nicky Cullum, Elizabeth McInnes, Sally BellSyer and Rosa Legood.

Early versions of this review have appeared as an Effective Healthcare Bulletin and a Cochrane review (Cullum N, Deeks, Sheldon T, Song, Fletcher A. Beds, mattresses and cushions for preventing and treating pressure ulcers. In: The Cochrane Library, Issue 2, 2004. Chichester, UK: John Wiley \& Sons, Ltd.

The authors would like to thank Margaret Harrison, David Margolis and Gerben ter Riet who peer reviewed the updated review and whose feedback contributed enormously to its final quality.

\section{REF ER E N C E S}

\section{References to studies included in this review}

Andersen 1982 \{published data only\}

* Andersen KE, Jensen O, Kvorning SA, Bach E. Decubitus prophylaxis: a prospective trial on the efficiency of alternating pressure air mattresses and water mattresses. Acta Dermatovener (Stockholm) 1982;63:227-30.

Aronovitch 1999 \{published data only\}

* Aronovitch SA, Wilber M, Slezak S, Martin T, Utter D. A comparative study of an alternating air mattress for the prevention of pressure ulcers in surgical patients. Ostomy/ Wound Management 99;45(3):34-40, 42-4. [MEDLINE: CN-00311344 - CCTR MEDLINE 1999276866]

Bennett 1998 \{published data only\}

* Bennett RG, Baran PJ, DeVone LV, Bacetti H, Kristo B, Tayback M, Greenough WB. Low airloss hydrotherapy versus standard care for incontinent hospitalized patients [see comments]. Journal of the American Geriatrics Society 1998;46(5):569-76.

Collier 1996 \{published data only\}

* Collier ME. Pressure-reducing mattresses. Journal of Wound Care 1996;5(5):207-11.

Conine 1990 \{published data only\} Conine TA, Daechsel D, Choi AK, Lau MS. Costs and acceptability of two special overlays for the prevention of pressure sores. Rehabilitation Nursing 1990;15(3):133-7. * Conine TA, Daechsel D, Lau MS. The role of alternating air and silicore overlays in preventing decubitus ulcers. International Journal of Rehabilitation Research 1990;13: 57-65.

Conine 1993 \{published data only\}

* Conine TA, Daeschel D, Hershler C. Pressure sore prophylaxis in elderly patients using slab foam or customised contoured foam wheelchair cushions. Occupational Therapy Journal of Research 1993;13(2):101-16.

Conine 1994 \{published data only\}

* Conine TA, Hershler C, Daechsel D, Peel C, Pearson

A. Pressure sore prophylaxis in elderly patients using polyurethane foam or Jay wheelchair cushions. International Journal of Rehabilitation Research 1994;17:123-137.

Cooper 1998 \{published and unpublished data\}

* Cooper PJ, Gray DG, Mollison J. A randomised controlled trial of two pressure reducing surfaces. Journal of Wound Care 1998;7(8):374-6.

Daechsel 1985 \{published data only\}

* Daechsel D, Conine TA. Special mattresses: effectiveness in preventing decubitus ulcers in chronic neurologic patients. Archives of Physical Medicine and Rehabilitation 1985;66:246-248. 
Economides 1995 \{published data only\}

* Economides NG, Skoutakis VA, Carter CA, Smith VH. Evaluation of the effectiveness of two support surfaces following myocutaneous flap surgery. Advances in Wound Care 1995;8:49-53.

Ewing 1964 \{published data only\}

* Ewing MR, Garrow C, Presley TA, Ashley C, Kinsella NM. Further experiences in the use of sheep skins as an aid in nursing. The Australian Nurses' Journal 1964;Sept: 215-219.

Exton-Smith 1982 \{published data only\}

* Exton-Smith AN, Overstall PW, Wedgewood J, Wallace G. Use of the 'air wave system' to prevent pressure sores in hospital. The Lancet 1982;ii:1288-1290.

Gebhardt 1994 \{published data only\}

* Gebhardt K. A randomized trial of alternating pressure (AP) and constant low pressure (CLP) supports for the prevention of pressure sores. Journal of Tissue Viability 1994;4(3):93.

Gebhardt K, Bliss MR. A controlled study to compare the efficacy, practicability and cost of pressure relieving supports to prevent and heal pressure sores. 2nd European Conference on Advances in Wound Management. 1992. Gebhardt KS, Bliss MR, Winwright PL. A randomised controlled trial to compare the efficacy of alternating and constant low pressure supports for preventing pressure sores in an intensive care unit. Personal Communication 1994. Gebhardt KS, Bliss MR, Winwright PL, Thomas J. Pressure relieving supports in an ICU. Journal of Wound Care 1996;5 (3):116-21.

Gentilello 1988 \{published data only\}

* Gentilello L, Thompson DA, Tonnesen AS, Hernandez D, Kapadia AS, Allen SJ, et al.Effect of a rotating bed on the incidence of pulmonary complications in critically ill patients. Critical Care Medicine 1988;16:783-786.

Goldstone 1982 \{published data only\}

* Goldstone L, Norris M, O'Reilly M, White J. A clinical trial of a bead bed system for the prevention of pressure sores in elderly orthopaedic patients. Journal of Advanced Nursing 1982;7:545-548.

Gray \& Campbell 1994 \{published data only\} Gray D. [A randomised controlled trial of two foam mattresses]. Journal of Tissue Viability Society's 22nd Conference. 1994:4.

* Gray DG, Campbell M. A randomized clinical trial of two types of foam mattresses. Journal of Tissue Viability 1994;4: 128-132.

Gray DG, Cooper PJ, Campbell M. A study of the performance of a pressure reducing foam mattress after three years of use. Journal of Tissue Viability 1998;8(3):9-13.

Gray \& Smith 1994 \{published data only\}

* Gray D, Smith M. A randomized controlled trial of two pressure-reducing foam mattresses. European Wound Management Conference. 1998.
Gunningberg 2000 \{published data only\}

* Gunningberg L, Lindholm C, Carlsson M, Sjoden P-O.

Effect of visco-elastic foam mattresses on the development of pressure ulcers in patients with hip fractures. Journal of Wound Care 2000;9(10):455-60.

Hampton 1997 \{published and unpublished data\}

* Hampton S. Evaluation of the new Cairwave Therapy System in one hospital trust. British Journal of Nursing 1997;6(3):167-70.

Hofman 1994 \{published data only\}

* Hofman A, Geelkerken RH, Hamming JJ, et al.Pressure sores and pressure-decreasing mattresses: controlled clinical trial. Lancet 1994;343:568-71.

Inman 1993 \{published data only\}

* Inman KJ, Sibbald WJ, Rutledge FS, et al.Clinical utility and cost-effectiveness of an air suspension bed in the prevention of pressure ulcers. Journal of the American Medical Association 1993;269:1139-1143.

Kemp 1993 \{published data only\}

* Kemp MG, Kopanke D, Tordecilla L, et al.The role of support surfaces and patient attributes in preventing pressure ulcers in elderly patients. Research in Nursing and Health 1993;16:89-96.

Keogh \& Dealey 2001 \{published data only\} Dealey C, Keogh A. A randomised controlled trial comparing the effexct of using an electric profiling bed with standard hospital bed for patients at high risk of pressure sore development. Advances in Wound Management. 2000.

* Keogh A, Dealey C. Profiling beds versus standard hospital beds: effects on pressure ulcer incidence outcomes. Journal of Wound Care 2001;10(2):15-9.

Laurent 1997 \{unpublished data only\}

* Laurent S. Effectiveness of pressure decreasing mattresses in cardiovascular surgery patients: a controlled clinical trial. 3rd European Conference for Nurse Managers. Brussels, October 1997.

Lazzara 1991 \{published data only\}

* Lazzara DJ, Buschmann MBT. Prevention of pressure ulcers in elderly nursing home residents: are special support surfaces the answer?. Decubitus 1991;4:42-26.

Lim 1988 \{published data only\}

${ }^{*}$ Lim R, Sirett R, Conine TA, et al.Clinical trial of foam cushions in the prevention of decubitis ulcers in elderly patients. Journal of Rehabilitation Research 1988;25:19-26.

McGowan 2000 \{published data only\}

McGowan S, Montgomery K, Jolley D, Wright R. [The role of sheepskins in preventing pressure ulcers in elderly orthopaedic patients]. First World Wound Healing Congress. 2000:108.

* McGowan S, Montgomery K, Jolley D, Wright R. The role of sheepskins in preventing pressure ulcers in elderly orthopaedic patients. Primary Intention 2000;8(4):1-8.

Munro \{published data only\} Munro BH, Brown L, Heitman BB. Pressure ulcers: one bed or another?. Geriatric Nursing 1989;10:190-2. 
Nixon 1998 \{published data only\}

Bridel-Nixon J, McElveney D, Brown J, Mason S. [Findings from a double-triangular sequential-design randomized clinical trial of a dry polymer pad]. New approaches to the management of chronic wounds: European Wound Management Association. London: Macmillan Magazines, 1997:20-21.

Bridel-Nixon J, McElveney D, Brown J, Mason S. A randomized controlled trial using a double-triangular sequential design: methodology and management issues. New approaches to the management of chronic wounds: European Wound Management Association. London: Macmillan Magazines, 1997:65-6.

* Nixon J, McElvenny D, Mason S, Brown J, Bond S. A sequential randomised controlled trial comparing a dry visco-elastic polymer pad and standard operating table mattress in the prevention of postoperative pressure sores. International Journal of Nursing Studies 1998;35:1932-3.

Price 1999 \{published data only\}

* Price P, Bale S, Newcombe R, Harding K. Challenging the pressure sore paradigm. Journal of Wound Care 1999;8(4): 187-190.

Russell 2000 \{published and unpublished data\}

Dunlop V. Preliminary results of a randomised controlled study of a pressure ulcer prevention system. Advances in Wound Care 1998;11(3 (suppl 1)):14.

Lichtenstein S. A 7 day comparative randomized parallel single centre study to determine the safety and efficacy of the Micropulse system for the prevention of pressure ulcers. Micropulse 1997.

* Russell JA, Lichtenstein SL. Randomised controlled trial to determine the safety and efficacy of a multi-cell pulsating dynamic mattress system in the prevention of pressure ulcers in patients undergoing cardiovascular surgery. Ostomy Wound Management 2000;46(2):46-51, 54-5.

Russell 2002 \{published data only\}

* Russell LJ, Reynolds TM, Park C, Rithalia S, Gonsalkorale $\mathrm{M}$, Birch J, et al.Randomised clinical trial comparing CONFOR-Med and standard hospital mattresses: results of the prevention of pressure ulcers study (PPUS-1). Advances in Skin \& Wound Care 2002;November:317-27.

Santy 1994 \{published data only\}

* Santy JE, Butler MK, Whyman JD. A comparison study of 6 types of hospital mattress to determine which most effectively reduces the incidence of pressure sores in elderly patients with hip fractures in a District General Hospital. Report to Northern \& Yorkshire Regional Health Authority. 1994.

Schultz 1999 \{published data only\}

Schultz A, Bien M, Dumond K, Brown K, Myers A.

Etiology and incidence of pressure ulcers in surgical patients. AORN Journal 1999;70(3):434, 437-40, 443-9.

* Schultz AA. Study results: prediction and prevention of pressure ulcers in surgical patients. Advances in Wound Care 1998;11(3 Suppl): 11 .
Sideranko 1992 \{published data only\}

* Sideranko S, Quinn A. Burns K, Froman RD. Effects of position and mattress overlay on sacral and heel pressures in a clinical population. Research in Nursing \& Health 1992; 15:245-251.

Stapleton 1986 \{published data only\}

* Stapleton M. Preventing pressure sores - an evaluation of three products. Geriatric Nursing 1986;6:23-25.

Summer 1989 \{published data only\}

* Summer WR, Curry P, Haponikm EF, Nelson S, Elston R. Continuous mechanical turning of intensive care unit patients shortens length of stay in some diagnostic-related groups. Journal of Critical Care 1989;4:45-53.

Takala 1996 \{published data only\}

* Takala J, Varmavuo S, Soppi E. Prevention of pressure sores in acute respiratory failure: a randomised controlled trial. Clinical Intensive Care 1996;7:228-235.

Taylor 1999 \{published data only\}

* Taylor L. Evaluating the Pegasus Trinova: a data hierarchy approach. British Journal of Nursing 1999;8(12):771-778.

Tymec 1997 \{published data only\}

* Tymec AC, Pieper B, Vollman K. A comparison of two pressure relieving devices on the prevention of heel pressure ulcers. Advances in Wound Care 1997;10:39-44.

Vyhlidal 1997 \{published data only\}

* Vyhlidal SK, Moxness D, Bosak KS, Van Meter FG, Bergstrom N. Mattress replacement or foam overlay? A prospective study on the incidence of pressure ulcers. Appl Nurs Res 1997;10(3):111-20.

Whitney 1984 \{published data only\}

* Whitney JD, Fellows BJ, Larson E. Do mattresses make a difference?. Journal of Gerontological Nursing 1984;10: 20-25.

\section{References to studies excluded from this review}

Allen 1993 \{published data only\}

* Allen V, Ryan DW, Murray A. Potential for bed sores due to high pressures: influence of body sites, body position, and mattress design. British Journal of Clinical Practice 1993;47(4):195-7.

Andrews 1989 \{published data only\} * Andrews J, Balai R. The prevention and treatment of pressure sores by use of pressure distributing mattresses. Care Science and Practice 89;7(3):72-6.

Ballard 1997 \{published data only\}

* Ballard K. Pressure-relief mattresses and patient comfort. Professional Nurse 1997;13(1):27-32.

Barhyte1995 \{published data only\}

* Barhyte DY, McCance L, Valenta A, Van Tatenhove J, Walker MS, Bethea S. Selection of a standard hospital mattress: data-based decision making. Journal of Wound Ostomy and Continence Nursing 1995;22:267-70. 
Bliss 1967 \{published data only\}

* Bliss MR, McLaren R, Exton Smith A N. Preventing pressure sores in hospital: controlled trial of a large-celled ripple mattress. British Medical Journal 1967;1(537):394-7. Bliss MR, McLaren R, Exton-Smith AN. Mattresses for preventing pressure sores in geriatric patients. Medical Bulletin of the Ministry of Health 1966

Bliss 1995 \{published data only\}

Bliss. Randomised controlled trial of seven pressure relieving mattress overlays for preventing pressure sores in elderly patients. Conference of Tissue Viability Society. 1994:5. * Bliss MR. Preventing pressure sores in elderly patients a comparison of seven mattress overlays. Age and Ageing 1995;24:297-302.

Braniff 1997 \{published data only\}

* Braniff-Matthews C, Rhodes J. Prevention versus treatment: long term management of care. New Approaches to the Management of Chronic Wounds. 1997:27-9.

Brienza 2001 \{published data only\}

* Brienza DM, Karg PE, Geyer MJ, Kelsey S, Trefler E. The relationship between pressure ulcer incidence and buttockseat cushion interface pressure in at-risk elderly wheelchair users. Archives of Physical Medicine and Rehabilitation 2001; 82(4):529-33.

Geyer MJ, Brienza D, Karg P, Kelsey S, Trefler E. Are commercial seat cushions efficacious in preventing pressure ulcers in the at-risk, elderly nursing home population?. The 13th Annual Symposium on Advanced Wound Care \& 10th Annual Medical Research Forum on Wound Repair. USA: HMP Communications, LLC., 2000.

Chaloner 1999 \{published data only\}

* Chaloner D. A prospective controlled comparison between two dynamic alternating mattress replacement systems within a community setting. 9th European Conference in Advances in Wound Management. Harrogate, 1999:9-11.

Chaloner 2000 \{published data only\}

* Chaloner D. A prospective, controlled comparison between two dynamic alternating mattress replacement systems within a community setting. 9th European Conference on Advances in Wound Managerment. 2000: 17.

Colin 1996 \{published data only\}

* Colin D, Loyant R, Abraham P, Saumet JL. Changes in sacral transcutaneous oxygen tension in the evaluation of different mattresses in the prevention of pressure ulcers. Advances in Wound Care 1996;9(1):25-8.

Conine 1991 \{published data only\}

* Conine TA, Hershler C. Effectiveness: a neglected dimension in the assessment of rehabilitation devices and equipment. International Journal of Rehabilitation Research 91;14:117-122.

deBoisblanc 1993 \{published data only\}

* deBoisblanc BP, Castro M, Everret B, Grender J, Walker CD, Summer WR. Effect of air-supported, continuous, postural oscillation on the risk of early ICU pneumonia in non-traumatic clinical illness. Chest 1993;103(5):1543-7.
DeFloor 2000 \{published data only\}

* Defloor T. The effect of position and mattress on interface pressure. Applied Nursing Research 2000;13(1):2-11.

Flam 1995 \{published data only\}

* Flam E, Isayeva E, Kipervas Y, Shklyarevsky V, Raab L.

Skin temperature and moisture management with a low air loss surface. Ostomy Wound Management 1995;41(9):50-6.

Fleischer 1997 \{published data only\}

* Fleischer I, Bryant D. Evaluating replacement mattresses. Nurse Management 1997;28(8):38-42.

Grindley 1996 \{published data only\}

* Grindley A, Acres J. Alternating pressure mattresses: comfort and quality of sleep. British Journal of Nursing 1996;5(21):1303-1310.

Gunningberg 1998 \{published data only\} * Gunningberg L, Lindholm C, Carlsson M, Sjoden PO. Patients with hip fracture: risk for pressure ulcers. A prospective, controlled study of 124 patients in Uppsala, Sweden. European Wound Management Association and Journal of Wound Care Autumn Conference. 98:10NT: HS.

Hampton 1998 \{published data only\}

* Hampton S. Can electric beds aid pressure sore prevention in hospitals?. British Journal of Nursing 1998;7(17):1010-7.

Hawkins 1997 \{published data only\}

* Hawkins JE. The effectiveness of pressure-reducing table pads as an intervention to reduce the risk of intraoperatively acquired pressure sores. Military Medicine 1997;162: 759-761.

Inman 1999a \{published data only\} * Inman, K. J, Dymock, K, Fysh, N, Robbins, B, Rutledge, F. S, Sibbald. W. J. Pressure ulcer prevention: a randomized controlled trial of 2 risk-directed strategies for patient surface assignment. Advances in Wound Care 1999;12: 72-80.

Jacksich 1997 \{published data only\}

* Jacksich BB. Pressure ulcer prevalence and prevention of nosocomial development: one hospital's experience. Ostomy Wound Management 43(3), 1997;43(3):32-4, 36, 38-40.

Jesurum 1996 \{published data only\} * Jesurum J, Joseph K, Davis JM. Balloons, beds and breakdown. Effects of low air loss therapy on the development of pressure ulcers in cardiovascular surgical patients with intra-aortic balloon pump support. Crit Care Nurs Clin North Am 1996;8(4):423-440.

Koo 1995 \{published data only\}

* Koo TKK, Mak AFT, Lee YL. Evaluation of an active seating system for pressure relief. Assistive Technology 1995; 7(2):119-128.

Marchand 1993 \{published data only\}

* Marchand AC, Lidowski H. Reassessment of the use of genuine sheepskin for pressure ulcer prevention and treatment. Decubitus 1993;6(1):44-47. 
Ooka 1995 \{published data only\}

* Ooka, Kemp MG, McMyn R, Shott S. Evaluation of three types of support surfaces for preventing pressure ulcers in patients in a surgical intensive care unit. Journal of Wound Ostomy Continenc Nursing 1995;22(6):271-9.

Phillips 1999 \{published data only\}

* Phillips L. Providing correct pressure-relieving devices for optimum outcome. British Journal of Nursing 1999;8(21): 1447-1452.

Regan 1995 \{published data only\}

* Regan MB, Byers BH, Mayrovitz HN. Efficacy of a comprehensive pressure ulcer prevention programme in an extended care facility. Advances in Wound Care 1995;8(3): $51-5$.

Reynolds 1994 \{published data only\}

* Reynolds A, Suarez C. Pressure-reducing capability of Conforma II mattress overlay. Advances in Wound Care 1994;7:36-40.

Rosenthal 1996 \{published data only\}

* Rosenthal MJ, Felton RM, Hileman DL, Lee M, Friedman M. A wheelchair cushion designed to redistribute sites of sitting pressure. Arch Phys Med Rehabil 1996;77:278-82.

Scott 1995 \{published data only\}

* Scott F. Easing the pressure for hip fracture patients.

Nursing Times 95;91(29):30-31.

Scott 1999 \{published data only\}

* Scott EM, Baker EA, Kelly PJ, Stoddard EJ, Leaper DJ. Measurement of interface pressures in the evaluation of operating theatre mattresses. Journal of Wound Care 1999;8: $437-41$.

Scott 2000a \{published data only\}

* Scott EM. The prevention of pressure ulcers in the operating department. Journal of Wound Care 2000;9(1): $18-21$.

Stoneberg 1986 \{published data only\}

* Stoneberg C, Pitcock N, Myton C. Pressure sores in the homebound: one solution. American Journal of Nursing 1986;April:426-8.

Suarez 1995 \{published data only\}

* Suarez CH, Reynolds A. Pressure reduction with a hospitalized population using a mattress overlay. Ostomy Wound Management 1995;41:58-60, 62-3.

Takala 94 \{published data only\}

* Takala J, Soini HO, Soppi E, Kataja M, Olkkonen K. [Is it possible to reduce the risk factors of pressure sores by means of special mattresses?]. Duodecim 94;110(4):407-414.

Thomas 1994 \{published data only\}

* Thomas J. Support surface evaluation methodological and statistical considerations. Journal of Tissue Viability 1994;4 (3): 93 .

Wells 1984 \{published data only\}

* Wells P, Geden E. Paraplegic body-support pressure on convoluted foam, waterbed, and standard mattresses. Research in Nursing and Health 1984;7(2):127-33.
Wild 1991 \{published data only\}

* Wild D. Body pressures and bed surfaces. Nursing

Standard 1991;5(27):23, 25-7.

Zernike 1997 \{published data only\}

* Zernike W. Heel pressure relieving devices how effective are they?. Australian Journal of Advanced Nursing 1997;14

(4):12-9.

\section{References to studies awaiting assessment}

Büchner 1995 \{published data only\}

* Büchner T. [Comparison of 3 decubitus prevention measures stemming from the same principle - with reference to cost-benefit analysis]. Krankenpflege 1995;33(6):248-52.

Defloor 1997 \{published data only\} Defloor T. [The effect of position and mattress on the development of pressure sores]. Verpleegkunde 1997;12(3): $140-9$.

Geelkerken 1994 \{published data only\} Geelkerken RH, Breslau PJ, Hermans J, Wille J, Hofman A, Hamming JJ. [Anti-decubitus mattress (letter; comment)]. Nederlands Tijdschrift voor Geneeskunde 1994;138(36): 1834.

Haalboom 1994 \{published data only\} * Haalboom J R. [Anti-decubitus mattresses]. Nederlands Tijdschrift voor Geneeskunde 94;138(26):1309-10.

Holzgreve 1993 \{published data only\}

* Holzgreve A, Waldner M, Waldner PW, Hohlbach G. [Bed sore prophylaxis in patients with chronic arterial occlusive disease with a new thermoactive pressure alternating mattress]. Langenbecks Archiv fur Chirurgie 1993;Suppl Kongessbericht: 1117 .

Jolley 2004 \{published data only\}

Jolley DJ, Wright R, McGowan S, et al.Preventing pressure ulcers with the Australian Medical Sheepskin: an open label randomised controlled trial. Medical Journal of Australia 2004;180:324-7.

Neander 1996 \{published data only\} Neander KD, Michels S, Bering F, Rich A, Merseburg M. Effects of soft bedding on body perception and posture]. Pflege 1996;9(4):293-9.

\section{Additional references}

\section{Allman 1997}

Allman RM. Pressure ulcer prevalence, incidence, risk factors, and impact. Clinical Geriatric Medicine 1997;13(3): $421-36$.

Bliss 1993

Bliss MR, Thomas, JM. Clinical trials with budgetary implications: establishing randomised trials of pressurerelieving aids. Professional Nurse 1993;8(5):292-6.

\section{Choi 1992}

Choi SC, Nelson LD. Kinetic therapy in critically ill patients: combined results based on meta-analysis. Journal of Critical Care 1992;7:57-62. 


\section{Clark 1994}

Clark M, Watts S. The incidence of pressure sores during a National Health Service Trust Hospital during 1991.

Journal of Advanced Nursing 1994;20:33-36.

\section{Deeks 1998}

Deeks J. Odds ratios should be used only in case control studies and logistic regression analyses. BMJ 1998;317: $1155-1156$

\section{Dept of Health 1993}

Department of Health. Pressure sores: a key quality indicator. London: Department of Health, 1993.

\section{Higgins 2003}

Higgins JPT, Thompson, SG, Deeks, JJ, Altman DG. Measuring inconsistency in meta-analyses. BMJ 2003;327: 557-60.

\section{Kaltenhalter 2001}

Kaltenhaler E, Whitfield, Walters SJ, Akehurst RL, Paisley S. UK, USA and Canada: how do their pressure ulcer prevalence and incidence data compare?. Journal of Wound Care 2001;10:530-5.
Moher 2001

Moher D, Schulz KF, Altman D. The CONSORT statement: revised recommendations for improving the quality of reports of parallel-group randomized trials. CONSORT group. JAMA 2001;285(15):1987-91.

\section{References to other published versions of this review}

\section{Cullum 1995}

Cullum NA, Deeks JJ, Fletcher AW, Sheldon TA, Song F. Preventing and treating pressure sores. Quality in Health Care 1995;4:289-97.

\section{Cullum 2001}

Cullum N, Nelson EA, Flemming K, Sheldon T. Systematic reviews of wound care management: (5) Beds: (6) Compression: (7) Laser therapy, therapeutic ultrasound, electrotherapy and electromagnetic therapy. Health Technology Assessment 2001;5(9):1-221.

\section{Cullum 2003}

Cullum N, Nelson EA, Nixon JE. Pressure Sores. Clinical Evidence. Vol. 9, London: BMJ Publishing Group, June 2003:408-9.

* Indicates the major publication for the study 


\section{CHARACTERISTICS OF STUDIES}

\section{Characteristics of included studies [ordered by study ID]}

\section{Andersen 1982}

\begin{tabular}{|c|c|c|}
\hline Methods & \multicolumn{2}{|c|}{ Prevention Trial: RCT with 10 day follow up. Method of allocation unclear } \\
\hline Participants & \multicolumn{2}{|c|}{$\begin{array}{l}\text { Patients in acute setting at high risk of pressure ulcer development (Andersen scale), and without existing } \\
\text { pressure ulcers }\end{array}$} \\
\hline Interventions & \multicolumn{2}{|c|}{$\begin{array}{l}\text { 1. Standard hospital mattress (161) } \\
\text { 2. Alternating air mattress (AP) (166) } \\
\text { 3. Water filled mattress (air mattress for camping filled with water) (155) }\end{array}$} \\
\hline Outcomes & \multicolumn{2}{|c|}{$\begin{array}{l}\text { Incidence of pressure ulcers (skin examined on alternate days). } \\
\text { Grade } 2 \text { or greater ulcers (broken skin): } \\
\text { Alternating mattress: } 4.2 \% \text { ( } 7 / 166) \text {; Water mattress: } 4.5 \% \text { ( } 7 / 155) \text {; Standard mattress: } 13.0 \%(21 / 161)\end{array}$} \\
\hline Notes & \multicolumn{2}{|c|}{$\begin{array}{l}118 \text { out of } 600 \text { selected patients dropped out during first } 24 \text { hours. A priori sample size calculation. } \\
\text { AP easily punctures and in this study was not always set at optimum pressure. Water bed is heavy and } \\
\text { time-consuming to fill. Patients more satisfied with ordinary bed: complained of the noise and pressure } \\
\text { changes of AP }\end{array}$} \\
\hline \multicolumn{3}{|l|}{ Risk of bias } \\
\hline Item & Authors' judgement & Description \\
\hline Allocation concealment?? & Unclear & B - Unclear \\
\hline
\end{tabular}

Aronovitch 1999

\begin{tabular}{ll}
\hline Methods & Prevention Trial: 7 days follow-up \\
\hline Participants & $\begin{array}{l}18 \text { years old; free of pressure ulcers; undergoing elective surgery under GA, of at least } 3 \text { hours operative } \\
\text { time. No significant differences between groups for age, sex, race, weight, height, smoking status at } \\
\text { baseline but patients in conventional management group were at greater risk of pressure ulcer development } \\
\text { as defined by Knoll score }\end{array}$ \\
\hline Interventions & $\begin{array}{l}\text { 1. AP system intra and postoperatively (Micropulse) (112) Micropulse is thin pad with over 2,500 small } \\
\text { air cells in rows; } 50 \% \text { cells inflated at any time. }\end{array}$ \\
$\begin{array}{l}\text { 2. Conventional Management }(105) \text { Conventional management comprised use of a gel pad in the } \\
\text { operating room and a replacement mattress postop }\end{array}$ \\
\hline $\begin{array}{l}\text { 1. MicroPulse system } 1 \%(1 / 90) \text { however ulcer due to foreign body and considered "not related to the } \\
\text { bed" } \\
\text { 2. Conventional Management } 9 \%(7 / 80)(7 \text { patients developed } 11 \text { ulcers) Grade } 1: 1 \text { Grade } 2: 4 \text { Un- } \\
\text { stageable: } 6 \text { P<0.005 }\end{array}$
\end{tabular}




Notes MicroPulse system: Device was inadvertently turned off during treatments of 4 patients. 4 patients
asked to withdraw for various unreported reasons. 3 patients withdrew due to back pain. 12 patients
assigned to this group were placed on another surface postop for reasons unrelated to the surface.
2. Conventional Management Group: 6 patients were placed on the MicroPulse postop. Analysis was on
an intention-to-treat basis

Risk of bias

\begin{tabular}{|c|c|c|}
\hline Item & Authors' judgement & Description \\
\hline Allocation concealment?? & Unclear & D - Not used \\
\hline
\end{tabular}

Bennett 1998

Methods

Prevention Trial: Follow up 60 days.

Median length of follow up (days):

1. $4(1-60)$

2. $6(1-62) \mathrm{P}<0.017$

Participants Acute and long term care patients who were incontinent of urine and/or faeces, in bed $>16$ hours per day, with pressure ulcers grade 2 or below (or none). If urinary catheter present, this was removed in the LAL group (not control group). Most common diagnoses: sepsis; malignancy; fractured neck of femur; hypovolaemia; dementia

Interventions

1. Low Air Loss Hydrotherapy (LAL Hydro) (42) Clensicair (SSI/Hill Rom). Permeable fast drying filter sheet over low air loss cushions (circulating air). Urine collection device integral to bed

2. Standard care (56) Standard care comprised standard bed or foam, air, alternating pressure mattresses.

Skin care not standardised

Outcomes

Number of patients who developed any kind of skin lesion more than 1 day after enrolment:

$1.27 / 42(64 \%)$

$2.10 / 56(18 \%)$

Number of patients who developed pressure ulcers Grade 2-4:

1.8/42 (19\%)

$2.4 / 56$ (7\%) $\mathrm{P}=0.11$; NS

Number of patients with non-blanchable erythema (Grade 1):

1. $6 / 42(14 \%)$

2. $0 / 56 \mathrm{P}=0.008$

Only 26 ulcers present on enrolment, and only 3 of these were Grade 3 or 4 so no healing data presented

Notes

The first 68 patients were discounted and a further 26 patients of 116 withdrew. No intention to treat analysis. Nurses received special extra training for the LAL bed. LAL patients were interviewed about satisfaction, control patients were not. There were many nurse complaints about the LAL; firmly held belief that it was associated with more ulceration. 2 subjects in the LAL group developed hypothermia. Findings may not relate to subsequent products since developed

Risk of bias

Support surfaces for pressure ulcer prevention (Review) 
Bennett 1998 (Continued)

\begin{tabular}{lll}
\hline Item & Authors' judgement & Description \\
\hline Allocation concealment?? & Unclear & D - Not used \\
\hline
\end{tabular}

Collier 1996

Methods

Prevention Trial: RCT comparing 8 different foam mattresses; length of follow up not clear but patients assessed weekly. Allocation as follows: mattresses assigned to beds and coded numerically with only the principal investigator and ward link nurse aware of identity of each mattress. Mattresses then allocated to patients "as available"

\begin{tabular}{ll} 
Participants & Patients on a general medical ward; no further detail given \\
\hline Interventions & Comparison of 8 foam mattresses: \\
1. New Standard Hospital Mattress (Relyon) (130 mm) (9) & 2. Clinifloat (11) \\
3. Omnifoam (11) & 4. Softform (12) \\
5. STM5 (10) & 6. Therarest (13) \\
7. Transfoam (10) & 8. Vapourlux (14)
\end{tabular}

Outcomes Incidence of pressure ulcers. Patients were assessed at least weekly throughout the hospital stay. No patient developed a pressure ulcer of any grade during whole study

Notes

9 patients were allocated the Cyclone mattress however this group was withdrawn from the study at manufacturer's request and data not presented. All mattresses assessed for "grounding", deterioration of cover and contamination of inner foam core, interface pressures. No "grounding" of any mattresses during the evaluation period; softening of the centre of the foam base in Standard and Omnifoam mattress on completion of study (detected using a "fist test" of unknown reliability). All mattress covers remained intact and inner foam protected

\section{Risk of bias}

\begin{tabular}{|c|c|c|}
\hline Item & Authors' judgement & Description \\
\hline
\end{tabular}

$\begin{array}{lll}\text { Allocation concealment?? No N - Inadequate } & \text { No }\end{array}$

Conine 1990

Methods Prevention Trial: Sequential RCT with 3 month follow up. Method of allocation unclear

Participants

Patients with chronic neurological diseases aged 18-55 years with no evidence of skin breakdown for at least 2 weeks prior to the study. Patients in the 2 groups were well matched at baseline for key variables e.g. Norton score; sex; age; underweight/overweight; diagnoses; years as a wheelchair user; history of previous pressure ulcers; incontinence. Setting extended care facility for chronic neurological conditions 


\section{Conine 1990 (Continued)}

\begin{tabular}{ll}
\hline Interventions & $\begin{array}{l}\text { 1. Alternating pressure overlay (72) } \\
10 \mathrm{~cm} \text { air cells. Cycle time not stated, nor the make of overlay } \\
\text { 2. Silicore (Spenco) overlay (76) } \\
\text { siliconised hollow fibres in waterproofed cotton placed over standard hospital mattress (spring or foam). } \\
\text { All patients received usual care including 2-3 hourly turning; daily bed baths; weekly bath/shower; use } \\
\text { of heel, ankle and other protectors }\end{array}$ \\
\hline Outcomes & $\begin{array}{l}\text { Incidence of pressure ulcers (including Grade 1). Pressure ulcer status was checked by another researcher } \\
\text { blind to the study. Inter-rater reliability high. }\end{array}$ \\
Included grade 1 ulcers: \\
$\begin{array}{l}\text { 1. Alternating air overlay: } 54 \% \text { (39/72) } \\
\text { 2. Spenco overlay: 59\% (45/76) } \\
\text { The alternating air overlay group had a slightly lower than average 'Exton-Smith severity score' (1.59 vs } \\
\text { 1.69); a shorter than average healing duration (25 days vs } 29 \text { days), not statistically significant }\end{array}$ \\
$\begin{array}{l}\text { Alternating air overlay needed frequent monitoring and expensive prolonged repairs. It was reported } \\
\text { that the patients sank into the Silicore overlay and found it difficult to move. Patients complained of } \\
\text { bad odour build-up, instability (especially Silicore), and noise of the alternating pressure motor. High } \\
\text { dropout rate due to discomfort }\end{array}$ \\
\hline Notes
\end{tabular}

\section{Risk of bias}

\begin{tabular}{lll}
\hline Item & Authors' judgement & Description \\
\hline Allocation concealment?? & Unclear & B - Unclear \\
\hline
\end{tabular}

Conine 1993

\begin{tabular}{ll}
\hline Methods & Prevention trial with 3 month follow up \\
\hline Participants & $\begin{array}{l}\text { Extended care patients }>60 \text { years; free of skin breakdown for at least } 2 \text { weeks prior to study; considered } \\
\text { to be at high risk of pressure ulcers; sitting in wheelchair for a minimum of } 4 \text { consecutive hours; free of } \\
\text { any progressive disease which could lead to bed confinement }\end{array}$ \\
\hline Interventions & $\begin{array}{l}\text { 1. Slab cushion bevelled at base to prevent seat sling }(144) \\
\text { ischial bar }(144)\end{array}$ \\
\hline Outcomes & $\begin{array}{l}\text { 1. Slab cushion } 85 / 125(68 \%) \\
\text { 2. Contoured foam cushion } 84 / 123(68 \%)\end{array}$ \\
\hline Notes & No intention to treat analysis \\
\hline Risk of bias &
\end{tabular}

Item

Authors' judgement

Description 
Conine 1993 (Continued)

\begin{tabular}{l|l}
\hline Allocation concealment?? & Unclear \\
\hline
\end{tabular}

Conine 1994

\begin{tabular}{ll} 
Methods & $\begin{array}{l}\text { Prevention Trial: RCT of two wheelchair cushions with } 3 \text { month follow up. Method of randomisation } \\
\text { unclear as patients were described as "randomly allocated by the principal investigator" }\end{array}$ \\
\hline Participants & $\begin{array}{l}\text { Elderly patients (mean age } 82 \text { yrs) in an extended care hospital deemed at high risk of pressure ulcers } \\
\text { (Norton Score of } 14 \text { or less); sitting in a wheelchair daily for minimum of } 4 \text { consecutive hours; free of } \\
\text { progressive disease likely to confine them to bed. Excluded if diabetic, had peripheral vascular disease; } \\
\text { confined to bed for more than } 120 \text { consecutive hours (except if to heal a pressure ulcer). } \\
\text { There were no statistically significant differences between groups at baseline for Norton scores; age; hours } \\
\text { in bed/day; sex; diagnosis; sensory loss; history of previous ulcers; weight; nutritional status; oedema; } \\
\text { incontinence; hours in wheelchair/day }\end{array}$
\end{tabular}

Interventions
The Jay cushion is a contoured urethane foam base over gel pad
2. Foam cushion (73)
30kg per cubic metre density foam bevelled at the bottom to prevent sling effect
Both cushions fitted with identical Jay air-exchange covers of knitted polyester. Patients were assigned to
their specific wheelchairs by a seating specialist as per a local policy unaffected by the trial

1. Jay Cushion $17 / 68(25 \%)$
2. Foam Cushion $30 / 73(41 \%)$
Pressure ulcer incidence data is presented as number of ulcers and number of affected patients for all
grades of ulcer, but only as number of ulcers by Grade (and there were cases of multiple ulcers on the
same patient). Therefore it is impossible to present the incidence data as number of patients affected by
ulcers of Grade 2 or above

Notes $\quad 13 \%$ attrition; not analysed by intention to treat

\section{Risk of bias}

\begin{tabular}{lll}
\hline Item & Authors' judgement & Description \\
\hline Allocation concealment?? & Unclear & B - Unclear \\
\hline
\end{tabular}

\section{Cooper 1998}

\begin{tabular}{ll} 
Methods & $\begin{array}{l}\text { Prevention Trial: RCT with } 7 \text { day follow up. Allocation by consecutively numbered, sealed, opaque } \\
\text { envelopes }\end{array}$ \\
\hline Participants & $\begin{array}{l}100 \text { patients aged over } 65 \text { years, with no pressure ulcers, from three } 24 \text { bedded mixed emergency or- } \\
\text { thopaedic trauma wards. All patients at risk of pressure ulcers with Waterlow Risk scores of } 15 \text { and above. } \\
\text { Baseline variables similar for each group (age, sex, mobility, Waterlow scores) }\end{array}$
\end{tabular}




\section{Cooper 1998 (Continued)}

\begin{tabular}{|c|c|c|}
\hline Interventions & \multicolumn{2}{|c|}{$\begin{array}{l}\text { 1. Dry flotation mattress (Roho) (49) [Data supplied for only 43] } \\
\text { 2. Dry flotation mattress (Sofflex) (51) [Data supplied for only 41] }\end{array}$} \\
\hline Outcomes & \multicolumn{2}{|c|}{$\begin{array}{l}\text { Grade } 2 \text { and above: } 1 \text {. Roho mattress: } 2 \text {. Sofflex mattress: } 1 / 51(2 \%) \\
\text { Grade } 1 \text { ulcers: } 1 \text {. Roho mattress: } 5 / 43(12 \%) 2 . \text { Sofflex mattress } 2 / 41(5 \%)\end{array}$} \\
\hline Notes & \multicolumn{2}{|c|}{$\begin{array}{l}\text { Roho mattress: } 79 \% \text { patients found it comfortable or very comfortable } 5 \text { found it uncomfortable. Sofflex } \\
\text { mattress: } 90 \% \text { patients found it comfortable or very comfortable. Staff had difficulty setting the level of } \\
\text { inflation correctly; this can now be done automatically. } 16 \% \text { attrition; no intention to treat analysis }\end{array}$} \\
\hline \multicolumn{3}{|l|}{ Risk of bias } \\
\hline Item & Authors' judgement & Description \\
\hline Allocation concealment?? & Yes & A - Adequate \\
\hline
\end{tabular}

\section{Daechsel 1985}

\begin{tabular}{|c|c|c|}
\hline Methods & \multicolumn{2}{|c|}{ Prevention Trial: RCT with 3 month follow up. Method of allocation unclear } \\
\hline Participants & \multicolumn{2}{|c|}{$\begin{array}{l}32 \text { patients with chronic neurological conditions in a long term care hospital. All aged between } 19 \text { and } \\
60 \text { years, free from skin breakdown on entry, considered at high risk of pressure ulcers }\end{array}$} \\
\hline Interventions & \multicolumn{2}{|c|}{$\begin{array}{l}\text { 1. Alternating pressure mattress (Gaymar Inc)(16) } \\
\text { 2. Silicore overlay (JW Westman Inc)(16) }\end{array}$} \\
\hline Outcomes & \multicolumn{2}{|c|}{$\begin{array}{l}\text { Included grade } 1 \text { ulcers: } \\
\text { 1. Alternating overlay: } 25 \%(4 / 16) \\
\text { 2. Spenco overlay: } 25 \%(4 / 16) \\
\text { No statistically significant differences were found between the two groups with regard to location and } \\
\text { severity of pressure ulcers }\end{array}$} \\
\hline Notes & \multicolumn{2}{|c|}{$100 \%$ follow up. Patients' satisfaction was similar for both devices } \\
\hline \multicolumn{3}{|l|}{ Risk of bias } \\
\hline Item & Authors' judgement & Description \\
\hline Allocation concealment?? & Unclear & B - Unclear \\
\hline
\end{tabular}




\begin{tabular}{|c|c|c|}
\hline Methods & \multicolumn{2}{|c|}{ Prevention Trial: RCT with 2 week follow up. Allocation by sealed envelope } \\
\hline Participants & \multicolumn{2}{|c|}{$\begin{array}{l}12 \text { patients who had stage } 4 \text { pressure sores needing myocutaneous flap closure. } 10 \text { out of } 12 \text { participants } \\
\text { were paraplegic or quadriplegic. Groups appear broadly comparable at baseline except the ROHO group } \\
\text { seem to have slightly better nutritional status (not tested for significance) }\end{array}$} \\
\hline Interventions & \multicolumn{2}{|c|}{$\begin{array}{l}\text { 1. Roho dry flotation mattress (6) } \\
\text { Bed overlay consisting of } 720 \text { air cells that conform to the body to provide maximum support area and } \\
\text { a "floating" environment } \\
\text { 2. Air-fluidised Clinitron bed (6) } \\
\text { Ceramic microspheres through which warm pressurised air is blown, covered by a polyester sheet. The } \\
\text { bed forms a dry-fluid environment on which the patient floats so distributing body weight away from } \\
\text { bony prominences }\end{array}$} \\
\hline Outcomes & \multicolumn{2}{|c|}{$\begin{array}{l}\text { Wound breakdown: } 2 / 6 \text { on Roho vs } 2 / 5 \text { on Clinitron. No significant difference between two support } \\
\text { surfaces in the prevention of flap breakdown in the immediate post-operative period }\end{array}$} \\
\hline Notes & \multicolumn{2}{|c|}{ Do not appear to have had any withdrawals } \\
\hline \multicolumn{3}{|l|}{ Risk of bias } \\
\hline Item & Authors' judgement & Description \\
\hline Allocation concealment?? & Yes & A - Adequate \\
\hline
\end{tabular}

\section{Ewing 1964}

\begin{tabular}{|c|c|c|}
\hline Methods & \multicolumn{2}{|c|}{$\begin{array}{l}\text { Prevention and Treatment Trial: RCT with } 6 \text { months follow up. Mode of allocation unclear - stated as } \\
\text { random selection }\end{array}$} \\
\hline Participants & \multicolumn{2}{|c|}{$\begin{array}{l}\text { Elderly patients, average age } 72.5 \text { years, confined to bed, with reduced mobility in the legs due to } \\
\text { neurological disorder, or fixed joints, peripheral vascular disease. No baseline data given and baseline } \\
\text { comparability not described. Setting is the geriatric unit of a convalescent hospital }\end{array}$} \\
\hline Interventions & \multicolumn{2}{|c|}{$\begin{array}{l}\text { 1. The sheepskins were adjusted so that both legs were supported on the woolly fleece (18) } \\
\text { 2. Control, without sheepskins (18) All were submitted to the same 4-hourly routine skin care involving } \\
\text { washing, drying, powdering, light massage of pressure areas, bed cradle }\end{array}$} \\
\hline Outcomes & \multicolumn{2}{|c|}{ The study was too small and poorly designed to detect a difference. No reports of withdrawals } \\
\hline \multicolumn{3}{|l|}{ Notes } \\
\hline \multicolumn{3}{|l|}{ Risk of bias } \\
\hline Item & Authors' judgement & Description \\
\hline Allocation concealment?? & Unclear & B - Unclear \\
\hline
\end{tabular}


Exton-Smith 1982

Methods

Prevention Trial: RCT with 2 week follow up. Allocation by alternation and where the surface of choice was not available the patient was given an available surface

Participants

Newly-admitted geriatric patients, with fractured neck of femur, and long-stay patients; without pressure sores of grade 2 or greater. Norton score $<14$ Patients were matched in pairs for sex and Norton score. Where a match was not possible, the Airwave patient was matched with a Large Cell Ripple patient with a higher risk score. Groups appear well matched at baseline

Interventions

1. Pegasus Airwave system (31) 2 layers of air cells; pressure alternated by deflating every 3 rd cell in a 7 . 5 minute cycle. The mattress is ventilated with pinholes through which air passes to keep the patient's skin dry

2. Large Cell Ripple Mattress (31)

Large cell ripple not described

Outcomes

Grade 2 ulcer or greater

1. Airwave (AWS): 16\% (5/31)

2. Large Cell Ripple (LCR): 39\% (12/31)

Notes

During the trial period, no breakdowns with AWS, 10 breakdowns on LCR, 4 patients withdrawn; 94\% follow up

\section{Risk of bias}

\begin{tabular}{l|l|l}
\hline Item & Authors' judgement & Description \\
\hline Allocation concealment?? & No & C - Inadequate \\
\hline
\end{tabular}

Gebhardt 1994

\begin{tabular}{ll} 
Methods & $\begin{array}{l}\text { Prevention Trial: Allocation by case sheet number } \\
\text { Follow up mean } 16 \text { days }\end{array}$ \\
\hline Participants & $\begin{array}{l}\text { Newly admitted patients aged over } 18 \text { years with Norton score <14 and without existing ulcers. Patients } \\
\text { in ICU, oncology, medical, care of the elderly, orthopaedic wards. Groups well matched at baseline for } \\
\text { age, Norton score, sex }\end{array}$ \\
\hline Interventions & $\begin{array}{l}\text { 1. Alternating pressure air mattresses [various] (115) } \\
\text { 2. Constant low pressure (foam, fibrefill, air, water, gel) supports [various] (115) Patients with deteriorated } \\
\text { ulcers were transferred to more sophisticated medium cost support in the same group (e.g., Pegasus, } \\
\text { Nimbus, Orthoderm, Convertible, Roho) }\end{array}$ \\
\hline Outcomes & $\begin{array}{l}\text { Grade } 2 \text { or greater ulcer: } 1 . \text { Alternating pressure: } 16 \% \text { (18/115) } \\
\text { 2. Constant low pressure: } 55 \% \text { (63/115) }\end{array}$ \\
\hline Notes & $\begin{array}{l}\text { Analysis by intention to treat. Mechanical unreliability and poor management of alternating pressure } \\
\text { supports was a problem }\end{array}$ \\
\hline
\end{tabular}

\section{Risk of bias}


Gebhardt 1994 (Continued)

\begin{tabular}{lll}
\hline Item & Authors' judgement & Description \\
\hline Allocation concealment?? & No & C - Inadequate \\
\hline
\end{tabular}

\section{Gentilello 1988}

Methods Prevention Trial: RCT though method of allocation unclear. Duration of follow up unclear. Trial primarily not a pressure sore trial; kinetic treatment tables used to prevent chest infection in immobile patients

Participants Critically ill patients in surgical ICU immobilised because of head injury, spinal injuries or traction. Groups well matched at baseline for demographic and pulmonary risk factors; patients in the conventional bed group had higher incidence of cigarette smoking

Interventions

1. Kinetic Treatment Table (27)

Rotates through an arc of 124 degrees every 7 minutes. Nurses were instructed to leave the bed rotating except when vital signs being recorded and treatments given. If a patient developed a serious complication as result of KTT, they were moved onto conventional bed

2. Conventional beds (38)

Patients turned in conventional fashion every 2 hours. If a patient in this group developed a chest infection and positioning thought to be a factor the patient was moved onto a KTT

$\begin{array}{ll}\text { Outcomes } & \text { Primary outcomes were: } \\ & \text { Incidence of pulmonary complications } \\ & \text { Other outcomes measured included Incidence of pressure ulcers } \\ & \text { Kinetic Treatment Table } 30 \% \\ & \text { Conventional: } 26 \%\end{array}$

\section{Risk of bias}

\begin{tabular}{lll}
\hline Item & Authors' judgement & Description \\
\hline Allocation concealment?? & Unclear & B - Unclear \\
\hline
\end{tabular}

Goldstone 1982

Methods

Participants

Interventions
Prevention Trial: Patients allocated alternately to one of 2 alternative surfaces. Follow up not clear

Patients (>60 years) with femur fracture. (Mean Norton score 13) Groups comparable at baseline for age, Norton Score

1. Beaufort bead bed system which includes bead-filled mattress on A\&E trolley; bead-filled operating table overlay; bead-filled sacral cushion of operating table; bead-filled boots to protect heels on operating table (32)

2. Standard supports in A\&E, operating theatre, ward (43) 
Goldstone 1982 (Continued)

\begin{tabular}{ll} 
Outcomes & $\begin{array}{l}\text { Grading of ulcers was not given. Beaufort bed: } 16 \% \\
\text { Standard surface: } 49 \% \text { Maximum width of broken skin (mean): } 6.4 \mathrm{~mm} \text { on Beaufort beds vs } 29.5 \mathrm{~mm} \\
\text { on Standard }\end{array}$ \\
\hline Notes & $\begin{array}{l}\text { Patients who were found to be incontinent of urine (numbers not given) and in the Beaufort bead bed } \\
\text { group were catheterised however it does not seem to be the same for the control group. } \\
\text { Patients were removed from Beaufort bed standard surfaces due to unknown reasons. Number of with- } \\
\text { drawals unclear; no intention to treat analysis }\end{array}$ \\
\hline
\end{tabular}

\section{Risk of bias}

\begin{tabular}{lll}
\hline Item & Authors' judgement & Description \\
\hline Allocation concealment?? & No & C - Inadequate \\
\hline
\end{tabular}

\section{Gray \& Campbell 1994}

\begin{tabular}{|c|c|c|}
\hline Methods & \multicolumn{2}{|c|}{ Prevention Trial: RCT with 10 day follow up. Allocation by sealed envelope } \\
\hline Participants & \multicolumn{2}{|c|}{$\begin{array}{l}\text { Patients from orthopaedic trauma, vascular and medical oncology units without breaks in the skin } \\
\text { (Waterlow score }>15 \text { ) } \\
\text { Groups well matched at baseline for age, sex, Waterlow score }\end{array}$} \\
\hline Interventions & \multicolumn{2}{|c|}{$\begin{array}{l}\text { 1. Softfoam mattress }(90) \\
\text { 2. Standard } 130 \mathrm{~mm} \text { NHS foam mattress }(80)\end{array}$} \\
\hline Outcomes & \multicolumn{2}{|c|}{$\begin{array}{l}\text { Incidence of pressure ulcers. Skin condition assessed at } 5 \text { and } 10 \text { days; presumably assessor not blind to } \\
\text { treatment group. } \\
\text { Grade } 2 \text { or greater ulcer: } \\
\text { Softform: } 7 \% \\
\text { Standard: } 34 \% \\
\text { Rate of transfer to dynamic support surface: } 19 \% \text { in standard group vs } 2 \% \text { in Softform group }\end{array}$} \\
\hline Notes & \multicolumn{2}{|c|}{$\begin{array}{l}\text { Impossible to calculate attrition rate as incidence reported as } \% \text { only and unclear what the denominator } \\
\text { is. Nurses were more positive and patients gave higher comfort scores to Softform mattress }\end{array}$} \\
\hline \multicolumn{3}{|l|}{ Risk of bias } \\
\hline Item & Authors' judgement & Description \\
\hline Allocation concealment?? & Yes & A - Adequate \\
\hline
\end{tabular}


Gray \& Smith 1994

\begin{tabular}{|c|c|c|c|}
\hline Methods & \multicolumn{3}{|l|}{ Follow up 10 days } \\
\hline Participants & \multicolumn{3}{|c|}{$\begin{array}{l}\text { Patients admitted to a District General Hospital for bed rest or surgery, with intact skin, no other skin } \\
\text { abnormalities, no terminal illness, weight }<160 \mathrm{~kg} \text {. Mean Waterlow score on admission: } 1.14 \text { (3.6) } 2 \text {. } \\
13(2.5)\end{array}$} \\
\hline Interventions & \multicolumn{3}{|c|}{$\begin{array}{l}\text { 1. Transfoam mattress }(50) \\
\text { 2. Transfoamwave ( } 50) \text { (both foam) }\end{array}$} \\
\hline Outcomes & \multicolumn{3}{|l|}{$\begin{array}{l}\text { 1. } 1 \text { Grade IV ulcer } \\
\text { 2. } 1 \text { Grade II ulcer }\end{array}$} \\
\hline Notes & \multicolumn{3}{|c|}{$95 \%$ follow up; intention to treat analysis } \\
\hline \multicolumn{4}{|l|}{ Risk of bias } \\
\hline Item & Authors' judgement & \multicolumn{2}{|l|}{ Description } \\
\hline Allocation concealment?? & Unclear & \multicolumn{2}{|l|}{ D - Not used } \\
\hline \multicolumn{4}{|l|}{ Gunningberg 2000} \\
\hline Methods & \multicolumn{3}{|c|}{ Follow up until discharge or 14 days post-op } \\
\hline Participants & \multicolumn{3}{|c|}{$\begin{array}{l}\text { Patients admitted with a suspected hip fracture via an A\&E department who were }>65 \text { years and did not } \\
\text { have pressure ulcers }\end{array}$} \\
\hline Interventions & \multicolumn{3}{|c|}{$\begin{array}{l}\text { 1. } 10 \mathrm{~cm} \text { visco-elastic foam mattress on arrival in } \mathrm{A} \& \mathrm{E} \text { and visco-elastic foam overlay on standard ward } \\
\text { mattress (48) } \\
\text { 2. Standard A\&E trolley mattress and ward mattress (53) }\end{array}$} \\
\hline Outcomes & \multicolumn{3}{|c|}{$\begin{array}{l}\text { Grade II-IV incidence: } 1.4 / 48(8.3 \%) ; 2.8 / 53(15 \%) \text { Pressure ulcer incidence (all grades) } 1.12 / 48 \\
(25 \%) ; 2.17 / 53(32 \%) \\
\text { Mean comfort rating } 1.4 .2 ; 2.4 .0 \\
\text { All results non-significant }\end{array}$} \\
\hline Notes & \multicolumn{3}{|c|}{ Only 44 participants completed the comfort questionnaire } \\
\hline \multicolumn{4}{|l|}{ Risk of bias } \\
\hline Item & \multicolumn{2}{|l|}{ Authors' judgement } & Description \\
\hline Allocation concealment?? & \multicolumn{2}{|l|}{ Unclear } & D - Not used \\
\hline
\end{tabular}




\begin{tabular}{|c|c|c|}
\hline Methods & \multicolumn{2}{|c|}{$\begin{array}{l}\text { Prevention Trial: RCT but method of allocation not described. Duration of follow up to a maximum of } \\
20 \text { days }\end{array}$} \\
\hline Participants & \multicolumn{2}{|c|}{$\begin{array}{l}\text { Very little detail; average age } 77 \text { years. No data regarding baseline status of patients presented in the } \\
\text { published paper therefore impossible to judge baseline comparability. Only limited information obtained } \\
\text { on request: Number patients at high-very high risk Airwave Group }=31 \text {; Number patients at high-very } \\
\text { high risk Cairwave Group }=27 \text {. Mean age } A=79 \text { Mean Age } C=75\end{array}$} \\
\hline Interventions & \multicolumn{2}{|c|}{$\begin{array}{l}\text { 1. Alternating pressure (Cairwave System) (36) } \\
3 \text { cell, } 7.5 \text { minute cycle. Manufacturers claim that zero pressure achieved for more than } 20 \% \text { of the cycle } \\
\text { 2. Alternating pressure (Airwave System) (39) } \\
\text { Cells arranged in sets of } 3 \text { and are inflated in waves. } 7.5 \text { minute cycle; zero pressure said to be applied for } \\
15 \% \text { of the time }\end{array}$} \\
\hline Outcomes & \multicolumn{2}{|c|}{$\begin{array}{l}\text { Incidence of pressure ulcers. } \\
\text { No patient in this study developed a pressure ulcer }\end{array}$} \\
\hline Notes & \multicolumn{2}{|l|}{ Attrition unclear } \\
\hline \multicolumn{3}{|l|}{ Risk of bias } \\
\hline Item & Authors' judgement & Description \\
\hline Allocation concealment?? & Unclear & B - Unclear \\
\hline
\end{tabular}

Hofman 1994

Methods Prevention Trial: RCT with 2 week follow up. Patients randomised in blocks of 6 but method of randomisation not described

Participants Patients with a femoral-neck fracture and risk score $>8$ (Dutch consensus scale). Excluded patients with pressure ulcers of grade 2 or greater on admission.

Groups were similar at baseline for pressure ulcer risk; haemoglobin; total serum protein and serum albumin

Interventions

1. Cubed foam mattress (Comfortex DeCube mattress) (21)

Allows removal of small cubes of foam from beneath bony prominences

2. Standard hospital mattress (23)

Standard polypropylene SG40 hospital foam mattress.

Both groups were treated according to the Dutch consensus protocol for the prevention of pressure ulcers

Outcomes

Incidence of ulcers of Grade 2 or greater at 2 weeks. Outcome assessment not blind to treatment group. Patients were examined 1 and 2 weeks after surgery by two independent observers; disagreement resolved by a 3 rd observer.

Grade 2 or greater ulcers: Comfortex DeCube: 24\% (4/17); Standard: 68\% (13/19) Maximum pressure ulcer gradings were significantly higher for the standard mattress than the DeCube mattress at 1 and 2 weeks 


\section{Hofman 1994 (Continued)}

\begin{tabular}{|c|c|}
\hline Notes & $\begin{array}{l}78 \% \text { follow up. No intention to treat analysis. DeCube mattress was not always used correctly and its } \\
\text { size was not optimum for all patients. } \\
\text { A priori sample size calculation }\end{array}$ \\
\hline \multicolumn{2}{|l|}{ Risk of bias } \\
\hline Item & Authors' judgement \\
\hline Allocation concealment?? & B - Unclear \\
\hline \multicolumn{2}{|l|}{ Inman 1993} \\
\hline Methods & Prevention Trial: RCT with an average of 17 days follow up. Method of allocation unclear \\
\hline Participants & $\begin{array}{l}\text { Patients aged over } 17 \text { years with an Acute Physiology and Chronic Health Evaluation (APACHE II) score } \\
\text { greater than } 15 \text { who had an expected intensive care unit stay of }>3 \text { days }\end{array}$ \\
\hline Interventions & $\begin{array}{l}\text { 1. Low-air-loss beds (49) } \\
\text { 2. Standard ICU bed (49); patients rotated every } 2 \text { hours }\end{array}$ \\
\hline Outcomes & $\begin{array}{l}\text { Incidence of pressure ulcers reported in the trial as both ulcers per patient and patients with ulcers. We } \\
\text { have only extracted the incidence of patients developing ulcers. } \\
\text { Grade } 2 \text { or greater ulcers: Low-air-loss beds: } 12 \% \text {; Standard ICU bed: } 51 \% \text { Patients with multiple pressure } \\
\text { ulcers: } 2 \% \text { on Low-air-loss beds and } 24 \% \text { on standard ICU bed }\end{array}$ \\
\hline Notes & $\begin{array}{l}\text { A priori sample size calculation. } 98 / 100 \text { patients randomised completed the study ( } 1 \text { lost from each } \\
\text { group) as did not stay in ICU for } 3 \text { days; neither developed a sore. } \\
\text { No ITT analysis }\end{array}$ \\
\hline
\end{tabular}

\section{Risk of bias}

\begin{tabular}{lll}
\hline Item & Authors' judgement & Description \\
\hline Allocation concealment?? & Unclear & B - Unclear \\
\hline
\end{tabular}

\section{Kemp 1993}

\begin{tabular}{ll} 
Methods & Prevention Trial: RCT with 1 month follow up. Allocat \\
\hline Participants & $\begin{array}{l}\text { Inclusion criteria were: aged over } 65 \text { years, inpatients, } \\
\text { 65-98, } 58 \text { women, } 26 \text { men. Recruited from general } \\
\text { care. All patients free from pressure ulcers on admission } \\
\text { Groups similar for important variables at baseline }\end{array}$ \\
\hline Interventions & $\begin{array}{l}\text { 1. Convoluted foam overlay, } 3 \text { or } 4 \text { inches thick (45) } \\
\text { 2. Solid foam overlay } 4 \text { inches thick, sculptured (39) }\end{array}$
\end{tabular}




\section{Kemp 1993 (Continued)}

\begin{tabular}{lll}
\hline Outcomes & $\begin{array}{l}\text { Incidence of pressure ulcers assessed by Research Nurse presumably not blind to intervention. } \\
\text { Included grade } 1 \text { ulcers: } \\
\text { Convoluted foam overlay: } 47 \% ; \\
\text { Solid foam overlay: } 31 \%\end{array}$ \\
\hline Notes & All patients appear to have completed the study \\
\hline Risk of bias & Authors' judgement & Description \\
\hline Item & No & C - Inadequate \\
\hline Allocation concealment??
\end{tabular}

Keogh \& Dealey 2001

\begin{tabular}{|c|c|c|}
\hline Methods & \multicolumn{2}{|l|}{ Follow up 5-10 days } \\
\hline Participants & \multicolumn{2}{|c|}{$\begin{array}{l}\text { Patients from two surgical and two medical wards who were: }>18 \text { years; Waterlow score of } 15-25 \text {; tissue } \\
\text { damage no greater than grade } 1\end{array}$} \\
\hline Interventions & \multicolumn{2}{|c|}{$\begin{array}{l}\text { 1. Profiling bed with a pressure reducing foam mattress/cushion }(50) \\
\text { 2. Flat-based bed with a pressure relieving/redistributing mattress/cushion (50) }\end{array}$} \\
\hline Outcomes & \multicolumn{2}{|c|}{$\begin{array}{l}\text { 1. } 0 / 35 \\
\text { 2. } 0 / 35 \\
\text { Healing of existing grade } 1 \text { ulcers } \\
1.4 / 4 \\
2.2 / 10\end{array}$} \\
\hline Notes & \multicolumn{2}{|c|}{$\begin{array}{l}\text { The extent of follow-up difficult to ascertain. No difference between the groups in terms of transferring } \\
\text { in and out of bed }\end{array}$} \\
\hline \multicolumn{3}{|l|}{ Risk of bias } \\
\hline Item & Authors' judgement & Description \\
\hline Allocation concealment?? & Unclear & D - Not used \\
\hline
\end{tabular}

Laurent 1997

Methods

Prevention Trial: RCT with factorial design. Two pressure relieving mattresses used either in ICU (alternating pressure), or in post-ICU hospitalisation (constant low pressure), or in combination and compared in each case with the standard surface. Randomised "by blocks" - method of allocation unclear

Participants

Adults over 15 years of age, admitted for major cardiovascular surgery, hospital stay likely to be at least 5 days, with a period on ICU.

Little data provided regarding baseline comparability 
Laurent 1997 (Continued)

\begin{tabular}{ll}
\hline Interventions & 2 X 2 Factorial Design: \\
& 1: Standard Mattress ICU; Standard Mattress Postop (80) \\
& 2: Nimbus (AP) ICU; Standard Mattress Postop (80) \\
& 3: Standard Mattress ICU; Tempur (CLP) Postop (75) \\
& 4: Nimbus ICU; Tempur Postop (77) \\
\hline Outcomes & Incidence of ulcers of Grade 2 or above (partial or full thickness skin loss and worse): \\
& Group 1: $18 \%(14 / 80) ;$ \\
& Group 2: $13 \%(10 / 80) ;$ \\
& Group 3: $15 \%(11 / 75) ;$ \\
& Group 4: $13 \%(10 / 77)$ NS \\
\hline
\end{tabular}

A priori sample size calculation.
No reports of withdrawals

Risk of bias

\begin{tabular}{lll}
\hline Item & Authors' judgement & Description \\
\hline Allocation concealment?? & Unclear & B - Unclear \\
\hline
\end{tabular}

\section{Lazzara 1991}

Methods

Prevention and Treatment Trial: RCT (allocation by random number tables) in elderly nursing home population with 6 month follow up

Participants Nursing home residents at risk (Norton score greater than 15) of pressure ulcers. 9 out of the total 66 subjects had pressure ulcers on entry to the study

Interventions

1. Air filled (SofCare) overlay (33 randomised; 2 ulcer on admission; 10/31 developed a new one).

2. Gel mattress (33 randomised; 7 ulcer on admission; 8/26 developed a new one)

Outcomes

Grade 2 or greater ulcers:

1. Air overlay: $16 \%(5 / 31)$

2. Gel mattress: $15 \%(4 / 26)$

Notes

Interventions not well described. Of the 74 who entered the study, only those who participated for 4-6 months were included in the analysis (total of 66). 19 patients died and were excluded from the analysis but these might be at highest risk. It was difficult to maintain inflation of the air overlay: it also punctured easily. During the trial, 110 air overlays were used for 76 patients. Gel mattress was heavy

\section{Risk of bias}

\begin{tabular}{lll}
\hline Item & Authors' judgement & Description \\
\hline Allocation concealment?? & No & C - Inadequate \\
\hline
\end{tabular}


$\operatorname{Lim} 1988$

Methods

Prevention Trial: RCT with 5 month follow up. Patients were "randomly assigned" but method of allocation not described

Participants

62 residents of an extended care facility; aged 60 or over; free of pressure ulcers; at high risk of developing a sore (Norton score 14 or less); using a wheelchair for 3 or more hours per day; without progressive disease or confined to bed.

Groups well matched at baseline for sex, age, weight, Norton Score, Primary diagnosis, sensory status, time spent in wheelchair, mobility

Interventions

1. Foam slab cushion ( $2.5 \mathrm{~cm}$ medium density foam glued to $5 \mathrm{~cm}$ firm chipped foam) (26)

2. Contoured foam cushion (same foam as above; cut into a customised shape to relieve pressure on ischial tuberosities) (26)

Both cushions fitted with identical snug fitting covers of knitted polyester

\begin{tabular}{ll}
\hline Outcomes & Included grade 1 ulcers: \\
& 1. Slab foam: $73 \%(19 / 26) ;$ \\
& 2. Contoured foam: $69 \%(18 / 26)$ \\
& Mean severity score was 1.9 in the slab and 1.7 in the contoured $(\mathrm{P}>0.05)$, and the mean healing duration \\
& was 6.2 weeks in the slab and 5.4 weeks in the contoured group $(\mathrm{P}>0.05)$ \\
\hline Notes & $84 \%$ follow up. \\
\hline
\end{tabular}

\section{Risk of bias}

\begin{tabular}{lll}
\hline Item & Authors' judgement & Description \\
\hline Allocation concealment?? & Unclear & B - Unclear \\
\hline
\end{tabular}

McGowan 2000

Methods Prevention Trial:

Discharge from hospital, transfer to a rehab ward

Participants

Orthopaedic patients aged 60 or over; assessed at low or moderate risk of pressure ulcer development by Braden scale; intact skin; anticipated LOS greater than 48 hours

Interventions

1. Standard hospital mattress, sheet and an Australian Medical Sheepskin overlay; sheepskin heel and elbow protectors as required (155)

2. Standard hospital mattress, sheet with or without other low tech constant pressure devices as required

(142) Sheepskins were changed as required (at least every 3 days)

Outcomes

1. Sheepskin Group 14/155 (9\%) (21 ulcers) 7 developed 1 ulcer; 7 developed 2. None more severe than stage I.

2. Control Group 43/142 (30\%) (67 ulcers) 25 developed 1 ulcer; 7 developed 2; 11 three. 4 ulcers were stage II, 1 stage IV. Comfort was rated significantly greater in experimental group. Limb protectors difficult to keep in place 
McGowan 2000 (Continued)

One patient from each group withdrew prior to data collection. 6 patients in experimental group withdrew
because sheepskin to hot or irritable; 7 in the control group withdrew plus 3 in experimental group due
to protocol violations (no intention to treat). Patients in experimental group rated comfort significantly
higher than controls $(\mathrm{P}=<0.0001)$

Risk of bias

\begin{tabular}{lll}
\hline Item & Authors' judgement & Description \\
\hline Allocation concealment?? & Unclear & D - Not used \\
\hline
\end{tabular}

Munro

Methods

Participants

Interventions

Outcomes

Notes

Risk of bias

\begin{tabular}{lll}
\hline Item & Authors' judgement & Description \\
\hline Allocation concealment?? & Unclear & D - Not used \\
\hline
\end{tabular}

\section{Nixon 1998}

Methods

Prevention Trial: RCT with 8 day follow up. Telephone randomisation (i.e. full allocation concealment) stratified by centre, and age

Participants

Patients aged 55 years and over, admitted for elective major general, gynaecological or vascular surgery in supine or lithotomy position and free of pre-op pressure damage greater than Grade 1.

Groups well matched at baseline for age, sex, Braden score, type of surgery, duration of surgery, length of preop stay, proportion of time hypotensive during surgery

Interventions

1. Dry visco-elastic polymer pad on operating table (222)

2. Standard operating theatre table mattress plus Gamgee heel support (224)

Outcomes

Incidence and severity of pressure ulcers:

Overall incidence of pressure ulcers of 16\% (65/416)

1. Dry visco-elastic polymer pad on operating table $11 \%(22 / 205)$

2. Standard mattress $20 \%(43 / 211) \mathrm{P}=0.01 \mathrm{OR}=0.46$, 95\% CI 0.26-0.82.

$56 / 65$ episodes of skin damage were conversions from Grade 0 to Grade 1 ulcers. 


\section{Nixon 1998 (Continued)}

4/65 Grade 0 to Grade 2a conversions.

$5 / 65$ Grade 0 to Grade $2 \mathrm{~b}$ conversions. This data is not broken down by group

A priori sample size calculation. 133 paired assessments by 94 nurses for pre-study interrater reliability
assessments were undertaken. There was disagreement in only $2.2 \%$ assessments and only 2 disagreements
related to differentiating between Grade 1 and Grade 2 a ulcers (the remainder were Grade 0 and Grade
1). The majority were associated with heel assessments. In the recovery and ward area assessments, there
were discrepant assessments in only $8.5 \%$ cases and sensitivity analysis assessing the impact of this level
of misclassification on the overall result determined that the overall difference between the mattresses
remains.
Main endpoint data reported for 416 patients; incomplete data for 30 patients (lost forms 3; incomplete
postop skin assessment 27). The patients with incomplete data were not reported by group

\section{Risk of bias}

\begin{tabular}{lll} 
Item & Authors' judgement & Description \\
\hline Allocation concealment?? & Yes & A - Adequate \\
\hline
\end{tabular}

Price 1999

\begin{tabular}{|c|c|c|}
\hline Methods & \multicolumn{2}{|c|}{ Follow up 14 days postoperatively } \\
\hline Participants & \multicolumn{2}{|c|}{$\begin{array}{l}\text { Patients with fractured neck of femur and Medley score of greater than } 25 \text { (very high risk), aged over } 60 \\
\text { years }\end{array}$} \\
\hline Interventions & \multicolumn{2}{|c|}{$\begin{array}{l}\text { 1. Repose system (low pressure inflatable mattress and cushion in polyurethane material) ( } 40) \\
\text { 2. Nimbus III dynamic flotation plus TransCell cushion ( } 40 \text { ) All other care standard best practice including } \\
\text { regular repositioning }\end{array}$} \\
\hline Outcomes & \multicolumn{2}{|c|}{$\begin{array}{l}\text { Blister }+ \text { Grade II: } \\
\text { 1. At admission } 1+1 / 40 \text {; preoperatively, } 1+0 / 36 \text {; } \\
\text { at } 7 \text { days, } 2+1 / 32 \text {; } \\
\text { at } 14 \text { days, } 0+3 / 24 \\
\text { 2. At admission, } 0+2 / 40 \text {; preoperatively, } 1+3 / 37 \text {; } \\
\text { at } 7 \text { days } 1+0 / 31 \text {, } \\
\text { at } 14 \text { days, } 1+1 / 26\end{array}$} \\
\hline Notes & \multicolumn{2}{|c|}{80 patients were randomised; 50 in the final analysis i.e.. $38 \%$ attrition } \\
\hline \multicolumn{3}{|l|}{ Risk of bias } \\
\hline Item & Authors' judgement & Description \\
\hline Allocation concealment?? & Unclear & D - Not used \\
\hline
\end{tabular}


Russell 2000

Methods

Prevention Trial: RCT with 7 day follow up. Randomisation using sealed opaque envelope

Participants

Patients aged at least 18 years; undergoing scheduled cardiothoracic surgery under GA; surgery of at least 4 hours duration; free of pressure ulcers.

Both groups comparable at baseline for pressure ulcer risk (modified Knoll); history of previous ulceration; disease status; sex; age; weight; height

Interventions $\quad$ 1. MicroPulse System in the OR and post op (98)

2. Conventional care (gel pad in OR, standard mattress post op) (100)

Outcomes Incidence and severity of pressure ulcers:

1. MicroPulse System 2\%* (2/98)2. Conventional Management 7\% (7/100 patients developed 10 ulcers) Grade of Ulcers:1. MicroPulse: Grade 2: 22. Conventional: Grade 1: 2 Grade 2: 5 Grade 3: 3*1/2 discounted by original authors from their analysis as thought to occur for reasons "not related to the use of the MicroPulse system"!

Notes No equipment-related adverse events were reported

\section{Risk of bias}

\begin{tabular}{l|ll}
\hline Item & Authors' judgement & Description \\
\hline Allocation concealment?? & Yes & A - Adequate \\
\hline
\end{tabular}

Russell 2002

Methods

Median days in study presented by group by hospital. For the expt group median days ranged from: 814; control group 9-17.

Central allocation at trials office/pharmacy, sequentially numbered or coded vials

Participants

Elderly acute, orthopaedic and rehabilitation wards; > 65 years; Waterlow of $15-20$

Interventions

1. Visco-polymer energy absorbing foam mattress (CONFOR-Med)/cushion combination (562)

2. Standard mattress/cushion combination (604)

Outcomes

Development of non-blanching erythema or worse (including with and without blanching erythema on admission to trial)

1. $110 / 562(19.9 \%)$

2. $161 / 604$ (26.3\%) $\mathrm{P}=0.005$ Development of non-blanching erythema or worse

1. $48 / 562(8.5 \%)$

2. 66/604 (10.9\%) Non-significant

Data for ulcers of Grade $>1$ not presented separately

Notes Patient comfort scores non significant. NO adverse events reported

\section{Risk of bias}

\section{Item}

Authors' judgement

\section{Description}


Russell 2002 (Continued)

$\begin{array}{lll}\text { Allocation concealment?? } & \text { Yes } & \text { A - Adequate }\end{array}$

Santy 1994

Methods

Prevention Trial: RCT with 14 day follow up. Allocation by random number tables; degree of allocation concealment unclear

Participants

Patients aged over 55 years with hip fracture with or without pressure ulcers. Excluded: those with a pressure ulcer of grade 3 or 4 at entry.

Patients in each group well matched for age and Waterlow Score at baseline

Interventions
Deep cut foam cubes in 3 sections with loose fitting cover
2. NHS contract $(150 \mathrm{~mm})(64)$
Single block of high resilience foam. Zipped cover of PVC nylon
3. Vaperm (116)
Made from 4 layers of foam of varying density with holes for ventilation. Profiled heel and head sections
and 2 part cover
4. Therarest (136)
3 layers of foam; extra soft top layer; middle layer claimed to absorb and disperse pressure; bottom layer
prevents bottoming out
5. Transfoam (102)
150 mm thick layered foam with zipped cover of vapour permeable 2-way stretch material. Very high
density foam used with firm central core and firmed edge

Outcomes

Rates of removal from study due to skin deterioration:

Clinifloat 9\%

NHS contract $27 \%$

Transfoam $10 \%$

Therarest $11 \%$

Vaperm 8\%

Notes

$9 \%$ attrition. At interim analysis, Clinifloat and NHS Contract mattresses were removed from the study; Clinifloat due to superior performance and the NHS mattress due to high rates of pressure sore development. This explains why fewer patients on these surfaces. Omnifoam mattress showed foam collapse after six weeks and were withdrawn from use and replaced with Vaperm mattresses. Problems with mattress cover found on two Therarest mattresses, three Transfoam mattress covers, and three times with the Clinifloat mattress

\section{Risk of bias}

\begin{tabular}{lll}
\hline Item & Authors' judgement & Description \\
\hline Allocation concealment?? & No & C - Inadequate \\
\hline
\end{tabular}


Schultz 1999

\begin{tabular}{|c|c|c|}
\hline Methods & \multicolumn{2}{|l|}{ Follow up 6 days } \\
\hline Participants & \multicolumn{2}{|c|}{$\begin{array}{l}\text { Patients admitted for surgery lasting at least } 2 \text { hours in lithotomy position, aged } 18 \text { or over; admitted } \\
\text { with intact skin }\end{array}$} \\
\hline Interventions & \multicolumn{2}{|c|}{$\begin{array}{l}\text { 1. Experimental mattress overlay in OR made of foam with a } 25 \% \text { ILD of } 30 \text { pounds and density of } 1.3 \\
\text { (206) } \\
\text { 2. Usual care (padding as required, including gel pads, foam mattresses, donuts etc) (207) }\end{array}$} \\
\hline Outcomes & \multicolumn{2}{|c|}{$\begin{array}{l}\text { 1. Experimental OR mattress overlay } 55 / 206(27 \%) 6 \text { people had ulcers of Stage II or more } \\
\text { 2. Usual care } 34 / 207(16 \%) 3 \text { people had ulcers of Stage II or more. } \\
\text { Total number of ulcers }=13915 / 139 \text { ulcers } \\
\text { Grade II or more severe }(11 \%) \mathrm{p}=0.0111\end{array}$} \\
\hline Notes & \multicolumn{2}{|c|}{$\begin{array}{l}\text { Experimental product caused post-operative skin changes. Authors contacted for more information re- } \\
\text { lating to grade of ulcer by group }\end{array}$} \\
\hline \multicolumn{3}{|l|}{ Risk of bias } \\
\hline Item & Authors' judgement & Description \\
\hline Allocation concealment?? & Unclear & D - Not used \\
\hline
\end{tabular}

\section{Sideranko 1992}

\begin{tabular}{|c|c|}
\hline Methods & $\begin{array}{l}\text { Prevention Trial: RCT with mean follow up of } 9.4 \text { days. Method of randomisation not stated though } \\
\text { said to be "random" }\end{array}$ \\
\hline Participants & $\begin{array}{l}\text { Adult, surgical intensive care unit patients: SICU stay }>48 \mathrm{hr} \text {, without existing skin breakdown on } \\
\text { admission. Groups broadly similar at baseline although water mattress group appear to be heavier and } \\
\text { with shorter number of days in ICU (significance of these differences unclear) }\end{array}$ \\
\hline Interventions & $\begin{array}{l}\text { 1. Alternating air overlay - } 1.5 \text { ” thick Lapidus Airfloat System (20) } \\
\text { 2. Static air mattress - 4" thick Gay Mar Sof Care (20) } \\
\text { 3. Water mattress - 4" thick Lotus PXM } 3666 \text { (17) }\end{array}$ \\
\hline Outcomes & $\begin{array}{l}\text { Grade of ulcers not reported. } \\
\text { 1. Alternating air mattress: } 25 \%(5 / 20) \\
\text { 2. Static air mattress: } 5 \%(1 / 20) \\
\text { 3. Water mattress: } 12 \%(2 / 17)\end{array}$ \\
\hline
\end{tabular}

Notes

The trial is primarily about interface pressure and patient position, therefore there is relatively little detail about the incidence part of the study and no description of co-interventions.

No withdrawals reported

\section{Risk of bias}
Item
Authors' judgement
Description 
Sideranko 1992 (Continued)

\begin{tabular}{|c|c|}
\hline Allocation concealment?? & B - Unclear \\
\hline \multicolumn{2}{|l|}{ Stapleton 1986} \\
\hline Methods & Prevention Trial: Method of allocation - alternation. Duration of follow up unclear \\
\hline Participants & $\begin{array}{l}\text { Female elderly patients with fractured neck of femur without existing pressure ulcers, Norton score } 14 \\
\text { or less. Baseline data presented and groups well matched for age and Norton score }\end{array}$ \\
\hline Interventions & $\begin{array}{l}\text { 1. Large Cell Ripple (Talley) (32) } \\
\text { 2. Polyether foam pad } 2 \mathrm{ft} \times \mathrm{ft} \times 3 \text { inch thickness (34) } \\
\text { 3. Spenco pad (34) }\end{array}$ \\
\hline Outcomes & $\begin{array}{l}\text { Ulcers of Grade } 2 \text { or greater: } \\
\text { 1. Large Cell Ripple: } 34 \%(11 / 32) \text {; } \\
\text { 2. Polyether foam pad: } 41 \%(14 / 34) \text {; } \\
\text { 3. Spenco pad: } 35 \%(12 / 34) \\
\text { Grade } 3 \text { and greater: } \\
\text { 1. Large Cell Ripple: } 0 \% \text {; } \\
\text { 2. Foam pad: } 24 \% \text {; } \\
\text { 3. Spenco pad: } 6 \%\end{array}$ \\
\hline
\end{tabular}

Notes

45 Large Cell Ripple mattresses required 50 motor repairs and 90 material repairs during 12 month study. Patients did not like the feel of the ripples. No mention of withdrawals

\section{Risk of bias}

\begin{tabular}{lll}
\hline Item & Authors' judgement & Description \\
\hline Allocation concealment?? & No & C - Inadequate \\
\hline
\end{tabular}

Summer 1989

Methods

Prevention Trial: RCT - duration of follow up unclear. Randomisation by random sequences of letters corresponding to treatment groups however level of concealment unclear

Participants

Patients admitted to the Intensive Care Unit in diagnostic groups: sepsis-sepsis syndrome/pneumonia; respiratory. failure; drug overdose; metabolic coma; stroke/neuromuscular disease; adult respiratory distress syndrome. Groups comparable at baseline for Apache score; condition of pressure area at baseline not discussed

Interventions

1. Kinetic Treatment Table (43)

$7 \mathrm{ft} \times 3 \mathrm{ft}$ padded, vinyl covered platform on central rotating pivot which turns through an arc every 1.7 seconds. Reported to be of value in respiratory failure

2. Routine 2 hourly turning on conventional beds (43)

Outcomes

1 patient developed small facial ulcer on Kinetic Treatment Table; none on conventional beds 
Summer 1989 (Continued)

\begin{tabular}{lll}
\hline Notes & $3 / 86(3 \%)$ patients lost to follow up & \\
\hline Risk of bias & & \\
\hline Item & Authors' judgement & Description \\
\hline Allocation concealment?? & Unclear & B - Unclear \\
\hline
\end{tabular}

Takala 1996

\begin{tabular}{ll}
\hline Methods & $\begin{array}{l}\text { Prevention Trial: RCT with } 14 \text { day follow up. Randomisation influenced by mattress availability therefore } \\
\text { not concealed }\end{array}$ \\
\hline Participants & $\begin{array}{l}\text { Non trauma patients admitted to Intensive Care Unit who were expected to stay }>5 \text { days. Treatment } \\
\text { groups similar at baseline however not compared for degree of pressure sore risk }\end{array}$ \\
\hline Interventions & $\begin{array}{l}\text { 1. Carital Optima }(21): \text { constant low pressure mattress comprising } 21 \text { double air bags on a base. } \\
\text { 2. Standard hospital foam mattress }(19): 10 \mathrm{~cm} \text { thick foam density } 35 \mathrm{~kg} / \mathrm{m} 3\end{array}$ \\
\hline Outcomes & $\begin{array}{l}\text { 1. No ulcers } \\
\text { Grade } 1 \mathrm{~B} \text { (superficial and limited to the dermis) }\end{array}$ \\
\hline Notes & \begin{tabular}{l} 
Go $\%$ withdrawals; intention to treat analysis undertaken \\
\hline
\end{tabular}
\end{tabular}

\section{Risk of bias}

\begin{tabular}{lll}
\hline Item & Author' judgement & Description \\
\hline Allocation concealment?? & No & C - Inadequate \\
\hline
\end{tabular}

Taylor 1999

\begin{tabular}{ll}
\hline Methods & $\begin{array}{l}\text { Prevention Trial: } \\
\text { Discharge from hospital or death }\end{array}$ \\
\hline Participants & Hospital inpatients aged 16 or over, with intact skin, requiring a pressure relieving support \\
\hline Interventions & $\begin{array}{l}\text { 1. Alternating pressure mattress with pressure redistributing cushion (Pegasus Trinova) (22) } \\
\text { 2. Alternative alternating pressure system (unnamed) with pressure redistributing cushion (22) }\end{array}$ \\
\hline Outcomes & $\begin{array}{l}\text { 1. TriNova 0/22 } \\
\text { 2. Control 2/22 (both ulcers superficial) }\end{array}$ \\
\hline $\begin{array}{l}\text { Notes } \\
\text { Study underpowered. Comfort data was not reported for control group. Nurse acceptability: Intervention: } \\
\text { good to very good } \mathrm{n}=15 ; \text { acceptable } \mathrm{n}=1 \text {; Controls: Good to very good n=9; acceptable } \mathrm{n}=11\end{array}$ \\
\hline $\begin{array}{l}\text { Support surfaces for pressure ulcer prevention (Review) } \\
\text { Copyright } \odot \mathbf{2 0 0 8} \text { The Cochrane Collaboration. Published by John Wiley \& Sons, Ltd. }\end{array}$
\end{tabular}

Copyright $\odot 2008$ The Cochrane Collaboration. Published by John Wiley \& Sons, Ltd. 
Taylor 1999 (Continued)

\section{Risk of bias}

\begin{tabular}{lll}
\hline Item & Authors' judgement & Description \\
\hline Allocation concealment?? & Unclear & D - Not used \\
\hline
\end{tabular}

Tymec 1997

\begin{tabular}{ll}
\hline Methods & Prevention Trial \\
\hline Participants & $\begin{array}{l}52 \text { patients admitted to selected nursing units of a large hospital with a Braden score of }<16 \text { (risk); intact } \\
\text { skin on heels. } 23 \text { women and } 29 \text { men aged } 27-90 \text { years, mean age } 66.6 \pm 16.5 \text { yrs. Mean Braden score on } \\
\text { admission 11.8. } 21 \text { patients with respiratory conditions, } 6 \text { with cancer, } 5 \text { with CVA }\end{array}$ \\
\hline Interventions & $\begin{array}{l}\text { Factorial design evaluating effect of heel elevation device plus positioning and order of positioning. } \\
\text { 1. Foot Waffle (FDA approved, non abrasive vinyl boot with built in foot cradle and inflated air chamber) } \\
\text { 2. Hospital pillow under both legs from below knee to the Achilles tendon. Unclear how many patients } \\
\text { in each group }\end{array}$ \\
\hline Outcomes & $\begin{array}{l}\text { Number of pressure ulcers developed } \\
\text { 1. Foot Waffle, } 6\end{array}$ \\
\hline 2. Hospital pillow, 2 Denominators unclear \\
\hline Notes & Do not appear to be any losses \\
\hline
\end{tabular}

\section{Risk of bias}

\begin{tabular}{lll}
\hline Item & Authors' judgement & Description \\
\hline Allocation concealment?? & Unclear & D - Not used \\
\hline
\end{tabular}

Vyhlidal 1997

Methods Prevention Trial: RCT with 10-21 day follow up. Allocation to surfaces achieved by investigator drawing assignment out of a hat therefore extent of concealment inadequate

Participants

Patients newly admitted to a skilled nursing facility; estimated stay at least 10 days; free of pressure ulcers but at risk (Braden score $<18$ with subscale score of $<3$ in sensory perception, mobility or activity levels) Diagnoses: musculoskeletal $45 \%$ cardiovascular $27.5 \%$ neurological $12.4 \%$ others $15 \%$

Patients in the MAXIFLOAT group were younger though not significantly. Braden Scale scores (risk of pressure ulcer development) similar between groups at baseline Patients in the MAXIFLOAT group were significantly heavier and stayed on the mattress longer than the Iris group

Interventions

1. IRIS 3000; 4" thick foam overlay with dimpled surface (20)

2. MAXIFLOAT; mattress replacement in 5 sections (20). The mattress has a water/bacteria repellent top cover; is made of 1.5 " thick antimicrobial foam with a centre core of cut foam; has a nonremovable polyester fibre heel pillow and a water/bacteria proof bottom cover. 
Vyhlidal 1997 (Continued)

Subjects in both groups received standards of care according to the protocols of the organisation

\begin{tabular}{ll}
\hline Outcomes & All Grades of ulcer \\
1. IRIS $300060 \%(12 / 20)$ \\
Grade $1: 25 \%(4 / 20)$ \\
Grade 2: $40 \%(8 / 20)$ \\
2. MAXIFLOAT 25\% (5/20) \\
Grade 1: $10 \%(2 / 20)$ \\
Grade 2: $15 \%(3 / 20)$ \\
P=0.025 \\
Time to ulcer: \\
1. IRIS 3000 6.5 days \\
2. MAXIFLOAT 9.2 days (NS) \\
\hline
\end{tabular}

Notes

No record of any withdrawals. The IRIS 3000 is an overlay which goes on an existing mattress resulting (in the trial) in a bed height of 29 inches. One subject refused the IRIS because of the height of the bed. IRIS is lighter at $6.9 \mathrm{lb}$ than the MAXIFLOAT $(25 \mathrm{lb})$ and easier to manipulate however the latter is still lighter than standard hospital mattress (48 lb). IRIS can be sent home with patient. IRIS costs $\$ 38$ cf. $\$ 260$ for MAXIFLOAT

Risk of bias

\begin{tabular}{l|ll}
\hline Item & Authors' judgement & Description \\
\hline Allocation concealment?? & No & C - Inadequate \\
\hline
\end{tabular}

Whitney 1984

Methods

Prevention Trial: RCT with 8 day follow up. Method of allocation not stated - patients were "selected at random" for each group

Participants

Patients on medical-surgical units who were in bed for 20 hours daily. Most patients had relatively little skin breakdown. Ages ranged from 19 - 91 years; mean 63.2 years. Majority of patients were confused, lethargic, stuporous. Only 39\% classed as mentally alert

Baseline data not presented

Interventions
Consisted of 1343 " diameter air cells. 3 minute cycle
2. Convoluted foam pad (Eggcrate) (26)
Patients in both groups were turned every two hours

Outcomes

Changes in skin condition did not differ significantly between patients using the alternating pressure air mattress and the foam mattress (better: $20 \%$ vs $19 \%$; same: $60 \%$ vs $58 \%$; worse $20 \%$ vs $23 \%$ )

Notes

4 patients died. Analysis by intention to treat. Alternating pressure mattress: pump maintenance was costly, patients objected to the movement. The alternating mattress was more easily cleaned and retained its original properties over several weeks compared to the foam which compressed and flattened 


\section{Risk of bias}

\begin{tabular}{lll}
\hline Item & Authors' judgement & Description \\
\hline Allocation concealment?? & Unclear & B - Unclear \\
\hline
\end{tabular}

Allocation concealment rated as:

A Adequate

B Unclear

C Inadequate

D Not used

\section{Characteristics of excluded studies [ordered by study ID]}

\begin{tabular}{|c|c|}
\hline Study & Reason for exclusion \\
\hline Allen 1993 & No clinical outcomes, interface pressure only recorded \\
\hline Andrews 1989 & Not an RCT \\
\hline Ballard 1997 & Data recorded was comfort data no pressure sore outcomes \\
\hline Barhyte1995 & Not an RCT \\
\hline Bliss 1967 & Not an RCT. Patients were recruited to the trial based on their risk score \\
\hline Bliss 1995 & $\begin{array}{l}\text { Whilst } 8 \text { surfaces were evaluated in this prospective trial, not all surfaces were in the trial at any time therefore } \\
\text { the surfaces were not truly compared with one another contemporaneously. Furthermore it was possible for } \\
\text { patients to be re-randomised back into the study, and this occurred frequently; there were a total of } 457 \text { mattress } \\
\text { trials reported in only } 238 \text { patients. The data are not presented by patient; only by mattress trial. } \\
\text { Duplicate citation of Bliss } 1994\end{array}$ \\
\hline Braniff 1997 & Healing and prevention outcome data not separated \\
\hline Brienza 2001 & Study of pressure measurement \\
\hline Chaloner 1999 & Not an RCT, Controlled clinical trial. Duplicate citation with Chaloner D 2000 \\
\hline Chaloner 2000 & $\begin{array}{l}\text { Not an RCT, randomisation corrupted, authors report that randomisation compromised on the basis of bed } \\
\text { availability }\end{array}$ \\
\hline Colin 1996 & No clinical outcomes recorded, only transcutaneous oxygen tension measurements were taken \\
\hline Conine 1991 & Not an RCT \\
\hline
\end{tabular}


(Continued)

\begin{tabular}{|c|c|}
\hline deBoisblanc 1993 & Outcome incidence of pneumonia, no pressure sore outcomes \\
\hline DeFloor 2000 & Does not compare surfaces \\
\hline Flam 1995 & Outcome skin temperature and skin moiture level, no pressure sore outcomes \\
\hline Fleischer 1997 & Not an RCT \\
\hline Grindley 1996 & $\begin{array}{l}\text { Patients were crossed over between intervention groups at } 3 \text { days. Outcome used was the assessment of patient } \\
\text { comfort }\end{array}$ \\
\hline Gunningberg 1998 & Not an RCT. Study of risk calculation rather than prevention \\
\hline Hampton 1998 & Not an RCT \\
\hline Hawkins 1997 & Not an RCT. \\
\hline Inman $1999 \mathrm{a}$ & Comparison of a bed rental versus a bed purchase strategy not a comparison of surfaces \\
\hline Jacksich 1997 & Not an RCT \\
\hline Jesurum 1996 & Not an RCT \\
\hline Koo 1995 & Not an RCT, study of interface pressure in healthy volunteers \\
\hline Marchand 1993 & Not an RCT \\
\hline Ooka 1995 & Quasi randomised trial design \\
\hline Phillips 1999 & $\mathrm{~N}$ of 1 trial design \\
\hline Regan 1995 & $\begin{array}{l}\text { This study reports an audit of pressure sore incidence after implementation of a comprehensive pressure sore } \\
\text { policy; it is not a prospective RCT }\end{array}$ \\
\hline Reynolds 1994 & Not an RCT \\
\hline Rosenthal 1996 & Not an RCT \\
\hline Scott 1995 & Ongoing study \\
\hline Scott 1999 & No clinical outcomes, healthy volunteer study of interface pressures \\
\hline Scott $2000 \mathrm{a}$ & Not an RCT of beds and mattresses \\
\hline Stoneberg 1986 & Historical control group \\
\hline Suarez 1995 & Controlled clinical trial which records only pressure measurements \\
\hline
\end{tabular}


(Continued)

\begin{tabular}{l|l}
\hline Takala 94 & Not an RCT, outcome measure of interface pressure \\
\hline Thomas 1994 & Not an RCT \\
\hline Wells 1984 & Interface pressure measurements only recorded \\
\hline Wild 1991 & Interface pressure measurements \\
\hline Zernike 1997 & $\begin{array}{l}\text { Use of eggcrate foam as a heel pressure relieving device, intervention not a bed or mattress. Incidence of pressure } \\
\text { sores not reported }\end{array}$ \\
\hline
\end{tabular}


DATA AND ANALYSES

Comparison 1. Constant low pressure supports v Standard foam mattresses (SFM)

\begin{tabular}{lcclc} 
Outcome or subgroup title & $\begin{array}{c}\text { No. of } \\
\text { studies }\end{array}$ & $\begin{array}{c}\text { No. of } \\
\text { participants }\end{array}$ & Statistical method & Effect size \\
\hline $\begin{array}{l}\text { 1 Pressure ulcer incidence } \\
\quad 1.1 \text { Water }\end{array}$ & 1 & 316 & $\begin{array}{l}\text { Risk Ratio (M-H, Random, 95\% CI) } \\
\text { Risk Ratio (M-H, Random, 95\% CI) }\end{array}$ & $\begin{array}{l}\text { Totals not selected } \\
\text { Not estimable }\end{array}$ \\
$\begin{array}{l}1.2 \text { Bead Bed } \\
1.3 \text { Comfortex DeCube }\end{array}$ & 1 & 75 & Risk Ratio (M-H, Random, 95\% CI) & Not estimable \\
mattress & 1 & 36 & Risk Ratio (M-H, Random, 95\% CI) & Not estimable \\
$\begin{array}{l}1.4 \text { Softform mattress } \\
1.5 \text { Alternative foam }\end{array}$ & 2 & 644 & Risk Ratio (M-H, Random, 95\% CI) & Not estimable \\
$\begin{array}{l}1.6 \text { Hi spec foam } \\
\text { mattress/cushion }\end{array}$ & 1 & 1166 & Risk Ratio (M-H, Random, 95\% CI) & Not estimable \\
\hline
\end{tabular}

Comparison 2. Alternative Foam Mattress v Standard Foam Mattress

\begin{tabular}{lcclc} 
Outcome or subgroup title & $\begin{array}{c}\text { No. of } \\
\text { studies }\end{array}$ & $\begin{array}{c}\text { No. of } \\
\text { participants }\end{array}$ & Statistical method & Effect size \\
\hline $\begin{array}{c}\text { 1 Pressure ulcer incidence } \\
\begin{array}{l}\text { 1.1 Various alternatives } \\
\text { (pooled) }\end{array}\end{array}$ & 5 & 2016 & Risk Ratio (M-H, Random, 95\% CI) & $0.40[0.21,0.74]$ \\
$\begin{array}{l}\text { Pressure ulcer incidence UK } \\
\text { studies only }\end{array}$ & 4 & 1980 & Risk Ratio (M-H, Random, 95\% CI) & $0.40[0.21,0.74]$ \\
\hline
\end{tabular}

\section{Comparison 3. Comparisons Between Alternative Foam Supports}

\begin{tabular}{lcccc} 
Outcome or subgroup title & $\begin{array}{c}\text { No. of } \\
\text { studies }\end{array}$ & $\begin{array}{c}\text { No. of } \\
\text { participants }\end{array}$ & Statistical method & Effect size \\
\hline $\begin{array}{l}\text { Pressure ulcer incidence } \\
\quad \begin{array}{l}1.1 \text { alternative foam v } \\
\text { standard foam }\end{array}\end{array}$ & 1 & 505 & $\begin{array}{l}\text { Risk Ratio (M-H, Fixed, 95\% CI) } \\
\text { Risk Ratio (M-H, Fixed, 95\% CI) }\end{array}$ & $\begin{array}{c}\text { Totals not selected } \\
\text { Not estimable }\end{array}$ \\
$\begin{array}{l}\text { 1.2 Maxifloat Foam Mattress } \\
\text { v Iris Foam Overlay }\end{array}$ & 1 & 40 & Risk Ratio (M-H, Fixed, 95\% CI) & Not estimable \\
$\quad \begin{array}{l}1.3 \text { Solid Foam v Convoluted } \\
\text { Foam }\end{array}$ & 1 & 84 & Risk Ratio (M-H, Fixed, 95\% CI) & Not estimable \\
\hline
\end{tabular}




\begin{tabular}{|c|c|c|c|c|}
\hline Outcome or subgroup title & $\begin{array}{l}\text { No. of } \\
\text { studies }\end{array}$ & $\begin{array}{c}\text { No. of } \\
\text { participants }\end{array}$ & Statistical method & Effect size \\
\hline 1 Pressure ulcer incidence & & & Risk Ratio (M-H, Fixed, 95\% CI) & Totals not selected \\
\hline 1.1 Sofflex v ROHO & 1 & 84 & Risk Ratio (M-H, Fixed, 95\% CI) & Not estimable \\
\hline 1.2 Optima v SFM & 1 & 40 & Risk Ratio (M-H, Fixed, 95\% CI) & Not estimable \\
\hline $\begin{array}{l}1.3 \text { Gel Mattress v Air-filled } \\
\text { Overlay }\end{array}$ & 1 & 66 & Risk Ratio (M-H, Fixed, 95\% CI) & Not estimable \\
\hline $\begin{array}{l}\text { 1.4 Static Air Mattress v Water } \\
\text { Mattress }\end{array}$ & 1 & 37 & Risk Ratio (M-H, Fixed, 95\% CI) & Not estimable \\
\hline $\begin{array}{l}1.5 \text { Foam Overlay v Silicore } \\
\text { Overlay }\end{array}$ & 1 & 68 & Risk Ratio (M-H, Fixed, 95\% CI) & Not estimable \\
\hline 1.6 Sheepskin v no sheepskin & 1 & 297 & Risk Ratio (M-H, Fixed, 95\% CI) & Not estimable \\
\hline
\end{tabular}

Comparison 5. Alternating Pressure v Standard Foam Mattress

\begin{tabular}{lcccc} 
Outcome or subgroup title & $\begin{array}{c}\text { No. of } \\
\text { studies }\end{array}$ & $\begin{array}{c}\text { No. of } \\
\text { participants }\end{array}$ & Statistical method & Effect size \\
\hline $\begin{array}{l}\text { 1 Pressure ulcer incidence } \\
1.1 \text { AP v SFM }\end{array}$ & 1 & 327 & $\begin{array}{l}\text { Risk Ratio (M-H, Fixed, 95\% CI) } \\
\text { Risk Ratio (M-H, Fixed, 95\% CI) }\end{array}$ & $\begin{array}{c}\text { Totals not selected } \\
\text { Not estimable }\end{array}$ \\
\hline
\end{tabular}

Comparison 6. Alternating Pressure v Constant Low Pressure

\begin{tabular}{|c|c|c|c|c|}
\hline Outcome or subgroup title & $\begin{array}{l}\text { No. of } \\
\text { studies }\end{array}$ & $\begin{array}{c}\text { No. of } \\
\text { participants }\end{array}$ & Statistical method & Effect size \\
\hline 1 Pressure ulcer incidence & 8 & 1019 & Risk Ratio (M-H, Random, 95\% CI) & $0.82[0.57,1.19]$ \\
\hline $\begin{array}{l}1.1 \mathrm{AP} \text { (various) v CLP } \\
\text { (various) }\end{array}$ & 1 & 230 & Risk Ratio (M-H, Random, 95\% CI) & $0.38[0.22,0.66]$ \\
\hline $\begin{array}{l}1.2 \text { AP v Silicore or Foam } \\
\text { Overlay }\end{array}$ & 4 & 331 & Risk Ratio (M-H, Random, 95\% CI) & $0.91[0.72,1.16]$ \\
\hline $\begin{array}{l}1.3 \text { AP v Water or Static Air } \\
\text { Mattress }\end{array}$ & 3 & 458 & Risk Ratio (M-H, Random, 95\% CI) & $1.31[0.51,3.35]$ \\
\hline $\begin{array}{l}2 \text { AP devices versus silicore or } \\
\text { foam overlay }\end{array}$ & 4 & 331 & Risk Ratio (M-H, Fixed, 95\% CI) & $0.91[0.71,1.17]$ \\
\hline $\begin{array}{l}3 \text { AP devices versus water or static } \\
\text { air mattress }\end{array}$ & 3 & 458 & Risk Ratio (M-H, Fixed, 95\% CI) & $1.26[0.60,2.61]$ \\
\hline
\end{tabular}




\begin{tabular}{|c|c|c|c|c|}
\hline Outcome or subgroup title & $\begin{array}{l}\text { No. of } \\
\text { studies }\end{array}$ & $\begin{array}{c}\text { No. of } \\
\text { participants }\end{array}$ & Statistical method & Effect size \\
\hline 1 Pressure ulcer incidence & & & Risk Ratio (M-H, Fixed, 95\% CI) & Totals not selected \\
\hline $\begin{array}{l}1.1 \text { Std ICU/SFM post-ICU } \\
\text { v Nimbus AP ICU/SFM } \\
\text { post-ICU }\end{array}$ & 1 & 160 & Risk Ratio (M-H, Fixed, 95\% CI) & Not estimable \\
\hline $\begin{array}{l}1.2 \text { Std ICU/SFM post-ICU } \\
\text { v Std ICU/Tempur CLP } \\
\text { post-ICU }\end{array}$ & 1 & 155 & Risk Ratio (M-H, Fixed, 95\% CI) & Not estimable \\
\hline $\begin{array}{l}1.3 \mathrm{Nimbus} \text { AP ICU/SFM } \\
\text { post-ICU v Std ICU/Tempur } \\
\text { CLP post-ICU }\end{array}$ & 1 & 155 & Risk Ratio (M-H, Fixed, 95\% CI) & Not estimable \\
\hline $\begin{array}{l}\text { 1.4 Std ICU/SFM post-ICU v } \\
\text { Nimbus AP ICU/Tempur CLP } \\
\text { post-ICU }\end{array}$ & 1 & 157 & Risk Ratio (M-H, Fixed, 95\% CI) & Not estimable \\
\hline $\begin{array}{l}1.5 \text { Nimbus AP ICU/SFM } \\
\text { post-ICU v Nimbus } \\
\text { ICU/Tempur post-ICU }\end{array}$ & 1 & 157 & Risk Ratio (M-H, Fixed, 95\% CI) & Not estimable \\
\hline $\begin{array}{l}1.6 \mathrm{Std} \text { ICU/Tempur } \\
\text { post-ICU v Nimbus } \\
\text { ICU/Tempur post-ICU }\end{array}$ & 1 & 152 & Risk Ratio (M-H, Fixed, 95\% CI) & Not estimable \\
\hline
\end{tabular}

Comparison 8. Comparisons Between Alternating Pressure Devices

\begin{tabular}{lcccc} 
Outcome or subgroup title & $\begin{array}{c}\text { No. of } \\
\text { studies }\end{array}$ & $\begin{array}{c}\text { No. of } \\
\text { participants }\end{array}$ & Statistical method & Effect size \\
\hline $\begin{array}{l}\text { 1 Pressure ulcer incidence } \\
\text { 1.1 Airwave v Large Cell }\end{array}$ & 1 & 62 & $\begin{array}{c}\text { Risk Ratio (M-H, Fixed, 95\% CI) } \\
\text { Risk Ratio (M-H, Fixed, 95\% CI) }\end{array}$ & Totals not selected \\
$\begin{array}{l}\text { Ripple } \\
\text { 1.2 Airwave v Pegasus }\end{array}$ & 1 & 75 & Risk Ratio (M-H, Fixed, 95\% CI) & Not estimable \\
$\begin{array}{l}\text { Carewave } \\
1.3 \text { Trinova v control }\end{array}$ & 1 & 44 & Risk Ratio (M-H, Fixed, 95\% CI) & Not estimable \\
\hline
\end{tabular}


Comparison 9. Low Air Loss v Standard Bed

\begin{tabular}{|c|c|c|c|}
\hline Outcome or subgroup title & $\begin{array}{lc}\text { No. of } & \text { No. of } \\
\text { studies } & \text { participants }\end{array}$ & Statistical method & Effect size \\
\hline 1 Pressure ulcer incidence & & Risk Ratio (M-H, Fixed, 95\% CI) & Totals not selected \\
\hline $\begin{array}{l}2 \text { Incidence of patients developing } \\
\text { multiple sores }\end{array}$ & & Risk Ratio (M-H, Fixed, 95\% CI) & Totals not selected \\
\hline
\end{tabular}

Comparison 10. Air-Fluidised Therapy v Dry Flotation

\begin{tabular}{lcccc} 
Outcome or subgroup title & $\begin{array}{c}\text { No. of } \\
\text { studies }\end{array}$ & $\begin{array}{c}\text { No. of } \\
\text { participants }\end{array}$ & Statistical method & Effect size \\
\hline 1 Rate of wound breakdown & 1 & 12 & Risk Ratio (M-H, Fixed, 95\% CI) & $1.01[0.20,4.95]$ \\
\hline
\end{tabular}

Comparison 11. Kinetic Treatment Table v Standard

\begin{tabular}{|c|c|c|c|c|}
\hline Outcome or subgroup title & $\begin{array}{l}\text { No. of } \\
\text { studies }\end{array}$ & $\begin{array}{c}\text { No. of } \\
\text { participants }\end{array}$ & Statistical method & Effect size \\
\hline 1 Pressure ulcer incidence & & & Risk Ratio (M-H, Fixed, 95\% CI) & Totals not selected \\
\hline
\end{tabular}

\section{Comparison 12. Operating Table Gel Overlay v No Overlay}

\begin{tabular}{lcccc} 
Outcome or subgroup title & $\begin{array}{c}\text { No. of } \\
\text { studies }\end{array}$ & $\begin{array}{c}\text { No. of } \\
\text { participants }\end{array}$ & Statistical method & Effect size \\
\hline 1 Pressure ulcer incidence & & & Risk Ratio (M-H, Fixed, 95\% CI) & Subtotals only \\
\hline
\end{tabular}

Comparison 13. Micropulse System for Surgical Patients

\begin{tabular}{lcccc} 
Outcome or subgroup title & $\begin{array}{c}\text { No. of } \\
\text { studies }\end{array}$ & $\begin{array}{c}\text { No. of } \\
\text { participants }\end{array}$ & Statistical method & Effect size \\
\hline 1 Pressure ulcer incidence & 2 & 368 & Risk Ratio (M-H, Fixed, 95\% CI) & $0.21[0.06,0.70]$ \\
\hline
\end{tabular}

